Research Article/Araştırma Makalesi

Problem-posing Creativity of Primary School $6^{\text {th }}$ Grade Students and the Relationship between their Problem Posing Self-Efficacy and Problem Posing Creativity

\author{
Funda AYDIN GÜÇ*1 (D) Seda KESKIN 2 (D) \\ ${ }^{1}$ Giresun University, Faculty of Education, Giresun, Turkey, funda.guc@giresun.edu.tr \\ ${ }^{2}$ Giresun University, Institute of Science, Giresun, Turkey, sedakeskinn61@gmail.com.tr \\ * Corresponding Author: funda.guc@giresun.edu.tr
}

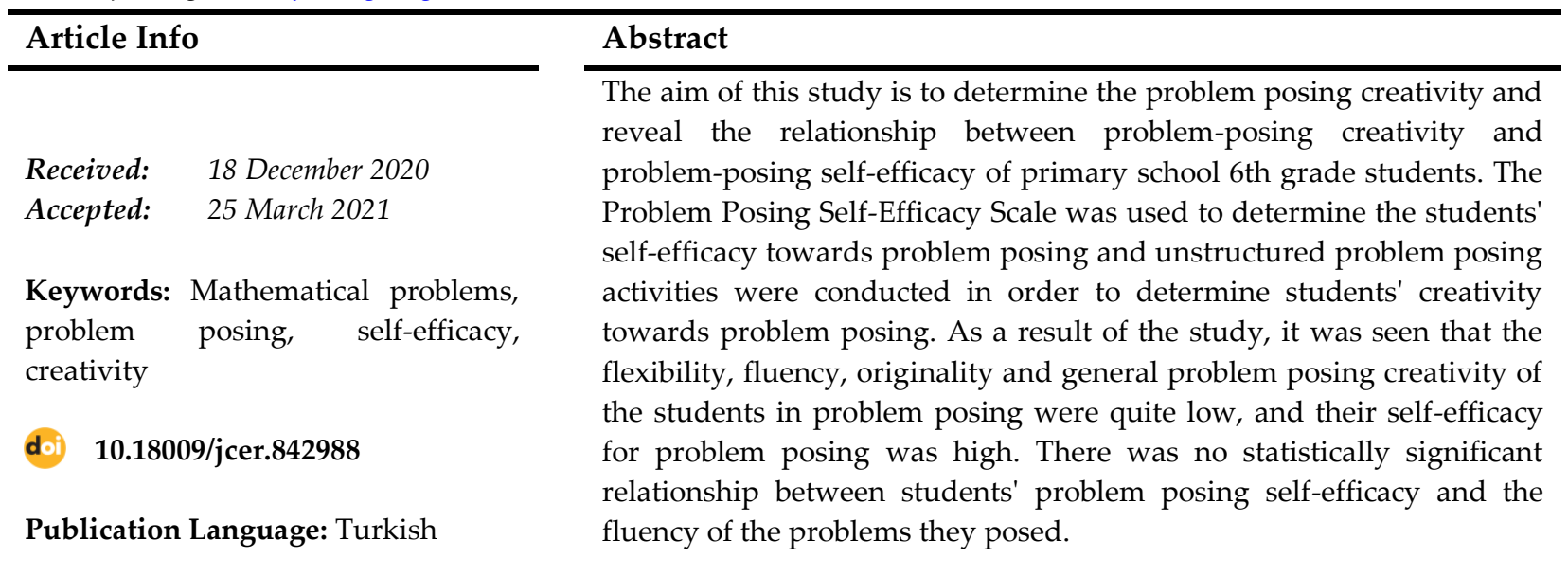

open access (

To cite this article: Aydın-Güç, F. \& Keskin, S. (2021). İlköğretim 6. sınıf öğrencilerinin problem kurma yaratıcılıkları ve problem kurma öz yeterlikleri ile problem kurma yaratıcılıkları arasındaki ilişkisi. Journal of Computer and Education Research, 9 (17), 145-176. DOI: 10.18009/jcer.794498

\title{
İlköğretim 6. Sınıf Öğrencilerinin Problem Kurma Yaratıcılıkları ve Problem Kurma Öz Yeterlikleri ile Problem Kurma Yaratıcılıkları Arasındaki İlişki
}

\begin{tabular}{|c|c|}
\hline Makale Bilgisi & Öz \\
\hline 18 Aralık 2020 & $\begin{array}{l}\text { Bu çalışmanın amacı, ilköğretim } 6 \text {. Sınıf öğrencilerinin problem kurma } \\
\text { yaratıcılıklarının belirlenmesi ve problem kurma yaratıcılıkları ile }\end{array}$ \\
\hline 25 Mart 2021 & $\begin{array}{l}\text { problem kurma öz yeterlikleri arasındaki ilişkinin ortaya koyulmasıdır. } \\
\text { Öğrencilerin problem kurma hakkındaki öz yeterliklerini tespit etmek }\end{array}$ \\
\hline $\begin{array}{l}\text { Anahtar kelimeler: Matematiksel } \\
\text { problemler, problem kurma, öz } \\
\text { yeterlik, yaratıcılik }\end{array}$ & $\begin{array}{l}\text { için Problem Kurma Öz Yeterlik Ölçeği uygulanmış, problem kurma } \\
\text { yaratıcılıklarını belirlemek için yapılandırılmamış problem kurma } \\
\text { çalışmaları yürütülmüştür. Çalışma sonucunda öğrencilerin problem } \\
\text { kurmada esnekliklerinin, akıcılıklarının, özgünlüklerinin ve genel } \\
\text { problem kurma yaratıcılıklarının oldukça düşük olduğu, problem }\end{array}$ \\
\hline doi) $10.18009 /$ jcer.794498 & $\begin{array}{l}\text { kurmaya yönelik öz-yeterliklerinin ise yüksek olduğu görülmüştür. } \\
\text { Öğrencilerin problem kurma öz yeterlikleri ile kurdukları problemlerin }\end{array}$ \\
\hline Yayım Dili: Türkçe & $\begin{array}{l}\text { akıcılıkları arasında ise istatistiksel olarak anlamlı bir ilişki olmadığı } \\
\text { görülmüştür. }\end{array}$ \\
\hline
\end{tabular}




\title{
Summary
}

\section{Problem-posing Creativity of Primary School $6^{\text {th }}$ Grade Students and the Relationship between their Problem Posing Self-Efficacy and Problem Posing Creativity}

\author{
Funda AYDIN GÜÇ 1 (D) Seda KESKİN 2 (iD) \\ ${ }^{1}$ Giresun University, Faculty of Education, Giresun, Turkey, funda.guc@giresun.edu.tr \\ ${ }^{2}$ Giresun University, Institute of Science, Giresun, Turkey, sedakeskinn61@gmail.com.tr \\ * Corresponding Author: funda.guc@giresun.edu.tr
}

\section{Introduction}

It is expected that the students involved in problem-posing develop their critical thinking and try to produce original ideas in order to pose a better problem in each problemposing activity, thus improving their creativity (English, 1997). Balka (1974), emphasizes that fluency, flexibility and originality are the three important indicators that should be taken into account in evaluating creativity and deals with creativity in mathematics within the scope of fluency, flexibility and originality in mathematical problem-posing processes. Fluency relates to the continuity of ideas, the flow of relationships and the use of general knowledge; flexibility is relevant to changing ideas, approaching a problem from different angles and producing many solutions; originality is associated with thinking in a unique way and the unique products of mental and artistic activity (Leikin, 2009). According to Silver (1994), fluency refers to the number of problems brought up or questions raised, flexibility refers to the number of different problem categories generated and originality indicates how rare the response is in the set of all answers. On the other hand, problem-posing self-efficacy causes students to be willing in the problem-posing process by considering themselves sufficient in problem-posing. The important thing here is that the students' ability to create a product with confidence, by making efforts in the problems (the difficulties they face). At the same time, the creativity of the product put forward in generating new products will serve as a step. It is clear that in order to create this productivity cycle, it is necessary to consider the self-efficacy of students while conducting problem-posing activities with them. Based on all this, the purpose of this study is to determine to determine the problem posing creativity and reveal the relationship between problem-posing creativity and problem-posing self-efficacy 
of primary school 6th grade students. In this context, the present study aimed to answer to the problem of "Is there a significant relationship between 6th grade students' self-efficacy and creativity in problem-posing?" The sub-problems of the study are as follows:

1. How is the problem posing creativity of primary school 6th grade students?

2. Is there a significant relationship between the self-efficacy of primary school 6th grade students in problem posing and the originality of the problems they have posed?

3. Is there a significant relationship between the self-efficacy of primary school 6th grade students in problem posing and the flexibility of the problems they have posed?

4. Is there a significant relationship between the self-efficacy of primary school 6th grade students in problem posing and the fluency of the problems they have posed?

\section{Method}

In determining the sample of the study, two primary schools were randomly selected in the Eastern Black Sea Region. 123 students who study in the 6th grade of selected primary schools and participate in the study voluntarily form the sample of the study. In order to measure the self-efficacy of students in problem-posing Problem-posing Self-efficacy Scale developed by Özgen and Bayram (2019) was used. The scale is of 5-point Likert type and consists of 24 items. In order to determine students' creativity towards problem posing, unstructured (free) problem posing studies were conducted. In the problem posing activities, by examining the learning outcomes in the mathematics curriculum (Ministry of National Education [MEB], 2018), the most appropriate 6 learning outcomes were determined and three unstructured problem posing activities were designed in this direction. The creativity of the problems posed by students was examined by considering the theoretical structure developed by Amaral and Carreira (2013) and revised by Taşkın (2016). In this structure, creativity is examined under the indicators of originality, flexibility, and fluency. First, the problems were checked by two researchers to see whether they were mathematical and solvable. The fluency, flexibility and originality scores of the problems were examined and the total creativity scores of the students were determined. After that, correlation analyses were conducted. 


\section{Results and Discussions}

As a result of the study, it was seen that the flexibility, fluency, originality and general problem posing creativity of the students in problem posing were quite low, and their selfefficacy for problem posing was high. Similar to current study results, studies (Arıkan, 2013; Bayazit \& Kırnap-Dönmez, 2017; Çetinkaya \& Soybaş, 2018; Korkmaz \& Gür, 2006; Özgen et al., 2017; Şengül \& Katranc1, 2012; Taşkın, 2016) also reveal that students' creativity is low in their problem posing performances. It was found that there is a statistically significant relationship $\left(r=.184^{*} ; \mathrm{p}=.042\right)$ between students' self-efficacy scores and creativity scores and that this relationship was weak. Studies show that there was a relationship between selfconfidence and problem posing performance (Bunar, 2011; Nicolaou \& Philippou, 2007; Özgen \& Bayram, 2019; Pajares, 1997). These studies were such as to support the results obtained in the present study. It was seen that there was a weak statistically significant relationship between students' problem posing self-efficacy scores and originality scores ( $\mathrm{r}=$ $\left..180^{*} ; \mathrm{p}=.046\right)$. In parallel, in the study of Kesgin (2006), it was stated that individuals with low self-efficacy had a narrower view of everything and could not be original. It was found that there was a weak statistically significant relationship between students' problem posing self-efficacy scores and originality scores $\left(r=.194^{*} ; \mathrm{p}=.032\right)$. The studies show that the students because of their lack of experience, could not have difference perspectives and therefore could not present creative problems (Şengül \& Katranc1, 2012) and that those who do not have enough self-efficacy perceive the events more difficult than they appear (Kesgin, 2006). In different to the literature, the existences of the relationships were also revealed statistically. There was no statistically significant relationship found between students' selfefficacy scores and fluency scores $(r=.132 ; \mathrm{p}=.146)$. In the present study, the problem posing creativity of the students was determined by unstructured problem posing activities. Alternatively, by using semi-structured and structured problem posing activities, it can be investigated whether results similar to the ones in this study would be obtained or not. 


\section{Giriş}

İnsanlar, hayatları boyunca birçok problemle karşılaşır. Karşılaştıkları problemlerin bazılarının farkına vararak bunlara çözümler üretirler. Bazılarının ise farkına bile varmazlar ve bu onların hayatında daha büyük sorunlar doğurur. Eğitimin içinde yer alan matematik gibi dersler gerçek yaşamda karşılaşılan problemler konusunda farkındalıklar oluşturur. Gerçek yaşamda karşılaşılan problemlerin farkına varılmasını sağlamakta problem kurmanın yerinin oldukça önemli olduğu söylenebilir (Turhan \& Güven, 2014) ve bu nedenle problem kurma matematiksel etkinliklerin merkezinde yer almaktadır (National Council of Teachers of Mathematics [NCTM], 2000).

\section{Problem Kurma}

Problem kurma birçok bilim insanı tarafından farklı tanımlanmıştır. Fakat genel bir tanım olarak problem kurma; problem çözücünün verilen bir problemin çözüm sürecinde problemi herhangi bir yolla yeniden oluşturduğu ve yeni problemler, matematiksel sorular üretmesi olarak tanımlanabilir (Nicolaou \& Philippou, 2007). Gerçek yaşam problemleriyle matematiksel problemler birebir aynı sayılmasalar da benzerdir. Matematiksel açıdan problem bireyin mevcut bilgileriyle ilk bakışta çözüm üretemediği sorundur (Grouws, 1996; Akt: Kayan \& Çakıroğlu, 2008). Dolayısıyla matematikte problem kurarken problem çözme sürecindeki zihinsel aktivitelerden de yararlanılır (Kırnap-Dönmez, 2014). Bu süreç içerisinde öğrencilerin kendi matematiksel problemlerini keşfederek ortaya koyması ve bu konuda yaratıcı olması da problem kurma sürecini içeren matematik eğitiminin bir parçası olmalıdır (Kilpatrick, 1987). Matematik öğretiminde önceden problem kurma konusunda öğrencilerden çok nadir kendilerini ifade etmeleri istenirdi (Tertemiz \& Sulak, 2013) ve günümüzde de ilköğretim matematik öğretiminde yeterli düzeyde yer aldığı söylenemez. Oysaki öğrencilerin problem kurma faaliyetleri içinde yer alması, öğrenirken daha aktif ve süreç içinde daha sorumluluk sahibi bir şekilde olmalarını sağlar (Nardone \& Lee, 2011). Bu önem dikkate alındığında, Türkiye'de de problem kurma faaliyetlerinin 2005 yılında matematik dersi öğretim programının yenilenmesiyle birlikte uygulanmada yer bulduğu söylenebilir.

Problem kurma farklı yaklaşımlarla ele alınarak öğrenme ortamlarına dahil edilmektedir. Bu yaklaşımları Stoyanova ve Ellerton (1996) yapılandırılmış (serbest), yarıyapılandırılmış ve yapılandırılmamış problem kurma etkinlikleri olarak sınıflandırmaktadır. 
Yapılandırılmamış problem kurma etkinliklerinde öğrenenlere örnek sorun verilmeden, onlardan doğal durumlara bağlı problemler üretmeleri beklenir (Stoyanova, 2003). Yarıyapılandırılmış problem kurma etkinliklerinde öğrencilerden verilen durumlardan, resimlerden, tablolardan, hikâyelerden veya grafiklerden yararlanarak (Özgen \& Bayram, 2019), keşfederek veya bildiklerini mevcut beceri, kavram ve önceden sahip oldukları matematiksel deneyimleriyle ilişkilendirerek problem kurmaları istenir (Stoyanova, 2003). Yapılandırılmış problem kurma etkinliklerinde ise öğrencilerden verilen özel bir probleme dayalı olarak problem üretmeleri beklenmektedir (Stoyanova, 2003). Çetinkaya ve Soybaş (2018), öğrencilerin hem yapılandırılmış ve hem de yapılandırılmamış problemleri kurmakta zorlandığını belirtirken; Özgen, Aydın, Geçici \& Bayram (2017), yapılandırılmamış problem kurma etkinliklerinde yol gösterecek verinin sınırlı olması nedeniyle öğrencilerin problem kurarken zorlandıklarını belirtmiştir. Yapılandırılmamış problem kurma faaliyetlerinde problemdeki verilenlerin, istenenlerin ve soru cümlesinin öğrenci tarafından oluşturulması beklenmektedir. Dolayısıyla öğrencilerin diğer problem kurma faaliyetlerine göre bu problem kurma faaliyetlerinde zorlanması doğal bir süreçtir. Çünkü burada hayal gücünü kullanmak ve yaratıcılık daha ön planda yer alır (Özgen vd., 2017). Her ne kadar öğrenciler problem kurma sürecinde zorlansa da bu etkinliklerin yürütüldüğü öğrenme ortamlarının hem öğrenciye hem de öğretmene birçok katkı sunması beklenmektedir.

Problem kurma sayesinde öğretmenler, öğrencilerinin ilgilendikleri ve merak ettikleri konular hakkında bilgi edinirler (Freire, 2018) böylece öğrencilerin konuları nasıl anlamlandırdıkları ve konular üzerindeki meraklarını ortaya koyarlar (Hiebert \& Wearne, 2003). Problem kurma, öğretmenler için öğrencilerin düşünme stillerine açılan bir pencere olarak kabul edilebilir (Cildir \& Sezen, 2011). Öğrenciler problem kurma esnasında özgün, sorgulayıcı ve üretim yaptıkları bir süreçten geçerler. Bu süreçte öğrencilerin matematiksel işlemleri ve kavramları kullanmaları, problemlerin çözülebilirliğini araştırmaları farklı düşünebilme becerilerini geliştirecektir. Problem kurma ile uğraşan öğrencinin eleştirel düşünmelerinin gelişmesi ve her problem kurma faaliyetinde bir öncekinden daha iyi problem kurmak için özgün fikirler üretmeye çalışması, böylece yaratıcılığının gelişmesi beklenir (English, 1997). Turhan ve Güven (2014), problem kurmanın öğrencilerin kendi derin düşünme yapılarını oluşturmaları için imkân sağladığını belirtmektedir. Arıkan (2013) ise öğrenenlerin eleştirel düşünmelerinin, akıl yürütmelerinin, bilgilerini organize edebilmelerinin gelişmesi için problem kurma faaliyetlerinin etkili bir araç olarak 
görülebileceğini vurgulamaktadır. Bu çerçevede problem kurma, yaratıcılık ve öz yeterlik kavramlarının ilişkilerinin ortaya koyulması önemlidir.

\section{Problem Kurmada Yaratıcılık}

Torrance (1966) yaratıcılığı; sorunlara, bilgi eksikliklerine, uyumsuzluklara duyarlı olmak, zorlukları belirlemek, zorluklara çözümler bulmak ve eksiklere yönelik hipotezler kurmak veya bunları değiştirmek, çözüm yollarını denemek hatta tekrar denemek ve bu sonuçları ortaya koymak olarak tanımlamaktadır (Akt: Alkan, 2014). Taylor'a (1960) göre yaratıcılık hem yeni hem de faydalı fikirlerin üretimi ile sonuçlanan düşünmedir. Haylock (1987) yaratıcılığı̆, geniş oranda bilişsel stilleri, performans kategorilerini ve sonuç türlerini ele alan bir kavram olarak tanımlamıştır. Yenilmez ve Yolcu'ya (2007) göre yaratıcılık bir süreci kapsarken bu sürecin sonundaki özgün ürünü de kapsamaktadır. Siswono'e (2011) göre yaratıcılık kişinin akıcılık ve esneklik olarak yeni fikirler ortaya atmak için kullandığ zihinsel süreçtir. Zeytun (2010) ise yaratıcılığı, daha önce var olmayan bir ürünün meydana getirilmesi ya da var olan bir ürünün farklı bir şekilde kullanılması olarak tanımlamıştır. Bu bağlamda yaratıcılığın tüm alanlarda var olduğunu ve matematiğin de bir ürün meydana getirmek işi olduğunu düşünürsek yaratıcılığın matematikte önemli bir yerinin olduğunu söyleyebiliriz. Chamberlin ve Moon (2005) matematikte yaratıcılı̆̆ın değerinin göz ardı edilmemesi gerektiğini belirtirken; Brunkalla (2009) matematikte kanıtların yaratılmasında yaratıcılığın önemli ve temel bir parça olduğunu vurgulamıştır.

Matematikte yaratıcılık kavramı da genel yaratıcılık gibi çok yönlü bir kavramdır (Siswono, 2011). Matematikte yaratıcılık, matematiğin mantıksal tümdengelimsel doğasını hesaba katarak yaratıılı̆̆ını ortaya çıkarmak anlamına gelmektedir (Leikin, 2009). Sriraman'a (2009) göre matematiksel yaratıcılık, yararlı ve yararsız kombinasyonlar arasında seçim yapabilme ve seviyesi ne olursa olsun yeni veya orijinal bir çalışma üretme yeteneği olarak tanımlanmaktadır. Balka'ya (1974) göre matematiksel yaratıcılık, neden-sonuç ilişkilerini araştıran hipotezleri matematiksel durumlar olarak formülize etmek, belli zekâ kalıplarından kurtulmak, özgün matematiksel fikirler üretmek ve bunları değerlendirmek, bir problemdeki eksikleri algılamak, matematiksel soruları sorabilmek ve problemleri alt problemlerine ayırmak gibi becerileri içermektedir. Bu bağlamda problem kurmanın veya mevcut bir problem üzerinde çeşitli değişiklikler yaparak onu yeni bir problem haline getirmenin yaratıcılığın önemli bir anahtarı olduğu vurgulanmaktadır (Jay \& Perkins, 1997). 
Silver (1994) ise problem kurmanın, yaratıcı aktivitenin veya özel yeteneğin bir özelliği olduğunu ifade etmektedir. Kojima, Miwa ve Matsui'e (2009) göre problem kurma, öğrencinin farklı yollarla yeni düşünceleri üretmelerini sağlar. Ayrıca Sriraman (2005) okul seviyesindeki matematikte yaratıcılığın, yeni problemleri formülleştirilme veya eski problemleri yeni bir açıdan ele almak şeklinde görülebileceğini dile getirmiştir. Bu tanımlamalardan yola çıkarak yaratıcılığın yeni bir problem üretmeyi, özgün problem formülize etmeyi içerdiği göz önüne alınarak problem kurma ile doğrudan ilişkili olduğu söylenebilir. Bu bağlamda problem kurma etkinliklerinde yaratıcılı̆̆ın nasıl ele alınması gerektiği incelenmelidir.

Balka (1974), yaratıcılığın değerlendirilmesinde göz önünde bulundurulması gereken üç önemli göstergenin akıcılık, esneklik ve orijinallik olduğunu vurgulamakta ve matematikteki yaratıcılığ 1 matematiksel problem kurma süreçlerinde akıcılık, esneklik ve özgünlük kapsamında ele almaktadır.

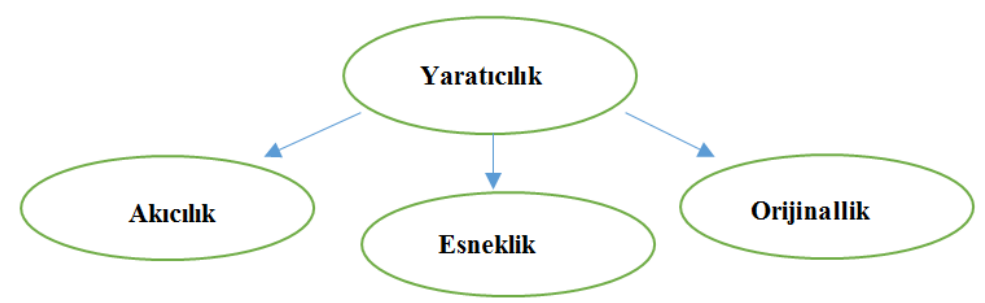

Şekil 1. Yaratıcılı̆̆ın Göstergeleri (Balka, 1974).

Akıcılık fikirlerin devamlılığı, ilişkilerin akışı ve genel bilginin kullanımı; esneklik fikirlerin değişimi, bir probleme farklı açılardan yaklaşma ve birçok çözüm üretilmesi; orijinallik eşsiz bir yolla düşünme ve zihinsel, sanatsal etkinliğin eşsiz ürünleri ile ilişkilidir (Leikin, 2009). Silver'a (1994) göre akıcılık, ortaya atılan sorunların veya ortaya çıkan soruların sayısını; esneklik üretilen farklı problem kategorilerinin sayısını ve orijinallik yanıtın tüm cevaplar kümesinde ne kadar nadir olduğunu ifade etmektedir. Budak (2007) akıcılığı kısaca bir problemle ilgili çok sayıda fikir üretme yeteneği, esnekliği kısaca kurulu bir yapıdan yeni bakış açılı üretkenliğe geçiş kabiliyeti, orijinalliği kısaca yeni ya da teknik özellikteki özgün düşünceler ortaya koymak, buluşlar yapabilmek, bir ürün bulmak veya değeri biçilemeyen yapıtlar ortaya koymak olarak tanımlamıştır. Bu tanımlar dikkate alındığında orijinal, esnek ve akıcı ürünler/problemler ortaya koymada bireyin kendine özgüven duyuyor olmasının süreç yönetimi ile ilişkili olduğu aşikardır. 


\section{Problem Kurma Öz Yeterliliğ $i$}

Problem kurma, mevcut konuyla ilgili yeni fikirler ortaya koymalarında öğrencilere yardımcı olduğu için bu konuda onları teşvik eder ve cesaretlendir (Brown \& Walter, 1990; Akt: Turhan \& Güven, 2014). Problem kurma sürecindeki bu cesaretlendirme ve güdülenme öz yeterliği meydana getirir. Böylece öz yeterliklerinin yüksek olması problem kurmaları için motivasyon sağlayacaktır. Bandura'ya (1997) göre, insanların belli durumlarla ilgilenme süreçlerindeki yeteneklerine yönelik yargıları kendi eylemlerine bağlıdır. Bu eylemler yapmayı seçtiklerini, etkinliklerde ne kadar çaba sarf ettiklerini, güçlüklere karşı ne kadar dayanıklı olduklarını içermektedir. Özel olarak problem kurma hakkındaki öz yeterlik, bireyin problemlerden, farklı matematiksel temsillerden veya gerçek yaşamdaki durumlardan yola çıkarak, farklı stratejiler kullanarak ve geçmiş tecrübelerinden de yararlanarak problem kurabilmesine yönelik öz yargısıdır (Özgen \& Bayram, 2019). Yani problem kurma öz yeterliği öğrencilerin kendilerini problem kurma konusunda yeterli görerek problem kurma sürecinde istekli olmalarına neden olmaktadır. Burada önemli olan öğrencilerin problemlerde (karşı karşıya geldikleri güçlüklerde) çaba göstererek özgüvenle ortaya bir ürün koyabilmesidir. Aynı zamanda yeni ürün oluşturmalarında ortaya koyulan ürünün yaratıcı olması basamak görevi görecektir. Bahsedilen üretkenlik döngüsünü oluşturmak için öğrencilerle problem kurma çalışmaları yaparken onların öz yeterliklerini göz önüne almak gerektiği açıktır.

\section{Yaratıcılık ve Öz yeterlilik}

Yaratıcı bireyler hem içinde yer aldığı toplum için hem de insanlığın gelişmesi için yarar sağlar (Gören-Summak \& Aydın, 2011). Bireylerin kendi yaratıcı düşünmelerini keşfetmesi, kendilerine inanmalarına ve bu konudaki kendilerine olan bakış açılarına kısacası öz yeterliklerine bağlıdır. Farklı davranma konusundaki cesaret, esnek olabilme, hata ve risklerini kabullenme, farklı bakış açılarına sahip olabilme, çabuk düşünebilme ve kavram oluşturabilme becerisi gibi farklı tutum, davranışlar yaratıcılığı etkiler (İraz, 2005). Aynı zamanda bu özelliklerin yer aldığı bireyler yüksek öz yeterliğe sahiptir; çünkü bu bireyler çevresel faktörleri olumlu yorumlamaya meyillidirler (Bakaç \& Özen, 2016). Yaratıcılık genellikle zaman ve çaba gerektiren zorlu bir faaliyet olduğundan başarısızlık riskini de göze alarak engeller karşısında sebat etmek gerekir. Bunu sağlayacak olan da 
çalışılan duruma yönelik öz yeterliktir. Bu konuda yaratıcılığın ve öz yeterliliğin ilişkisini ortaya koyan "yaratıcı sonuçlar üretme yeteneğine sahip olan inanç" olarak tanımlanan “yaratıcı öz yeterlik” kavramı karşımıza çıkmaktadır (Tierney \& Farmer, 2002). Yaratıcı özyeterlik, Bandura'nın (1997) daha genel öz-yeterlik kavramından türetilmiştir ve bir kişinin belirli bir ortamda başarılı bir şekilde performans gerçekleştirme inancı olarak açıklanmıştır. Dolayısıyla yaratıcılık ve öz yeterliliğin birbiri ile ilişkili olduğu aşikârdır. Tüm bunlardan yola çıkarak bu kavramları barındırıp detaylandıracak ve birbirleri ile ilişkilendirecek, öğrencilerin problem kurma öz yeterliklerinin yaratıcılık ile ilişkisinin incelendiği bir çalışmanın literatüre katkı sağlayacağı düşünülmektedir.

Literatür incelendiğinde öğrencilerin problem kurma performanslarında yaratıcılıklarının düşük (Arıkan, 2013; Bayazit \& Kırnap-Dönmez, 2017; Çetinkaya \& Soybaş, 2018; Korkmaz \& Gür, 2006; Özgen vd., 2017; Şengül \& Katranc1, 2012; Taşkın, 2016; Tertemiz \& Sulak, 2013) olduğu görülmektedir. Çetinkaya ve Soybaş (2018), öğrencilerin yapılandırılmamış problem kurma faaliyetleri gibi özgünlük ve yaratıcılık isteyen etkinliklerde başarısız olduklarını belirtmiştir. Ayrıca öğrencilerin kendilerini hem yarı yapılandırılmış ve hem de yapılandırılmamış problemleri kurmada yeterli görmediklerini ortaya koymuşlardır. Özgen ve diğerleri (2017); öğrencilerin yapılandırılmamış problem kurma konusunda yaratıcı olmadıklarını çünkü yapılandırılmamış problem kurma faaliyetlerinde öğrenciye örnek olacak verinin sınırlı miktarda olduğunu ortaya koymuştur. Korkmaz ve Gür (2006), matematik öğretmen adaylarının benzer tipte problemler kurduklarını ve matematiksel düşünme, akıl yürütme içeren, yaratıcı problemler kurmadıklarını ortaya koymuştur. Aynı zamanda kullanılan kitapları birer otorite olarak gördükleri için öğretmen adaylarının problemleri kitaptakine benzer yapıda kurdukları sonucuna ulaşmıştır. Şengül ve Katrancı (2012), öğretmen adaylarının deneyim eksikliklerinden dolayı yaratıcı problemler ortaya koyamadıklarını belirtmiştir. Tertemiz ve Sulak (2013), öğrencilerin basitçe problem kurmayı tercih ettiklerini; yeni bir bilgi eklemek, konuyu değiştirmek ve koşulları değiştirmek gibi üst düzeydeki becerileri ve yaratıcılığ gerektiren problemler kuramadıkları sonucuna ulaşmışlardır. Arıkan (2013), öğrencilerin gerçek hayat ile bağlantılı çok fazla problemle karşılaşmadıklarından dolayı kurdukları problemlerin birbirlerini taklit ettiğini ve yaratıcı olmadığını ortaya koymuştur. Bayazit ve Kırnap-Dönmez (2017), öğretmen adaylarının kurdukları problemleri incelediğinde yapılandırılmamış problem kurma etkinliklerinde yaratıcılığın azaldığını çünkü bu 
etkinliklerin sadece genel bir bağlam böylece yüksek düzeyde muhakeme, hayal gücü, yaratıcılık kullanmanın öğrenciler için zorlayıcı olduğunu belirtmiş ve bu durumun düşüncenin doğası gereği olduğunu aynı zamanda bilginin içeriğinden kaynaklandığını söylemiştir. Aynı zamanda, kurulan problemlerin yaratıcılıklarının problem kurucunun geçmiş deneyimlerinden ve sosyo-kültürel çevresinden etkilendiğini ortaya koymuştur. Taşkın (2016), öğrencilerin kurdukları problemleri incelediğinde özellikle özgünlük açısından yetersiz olduğunu ortaya koymuştur. Aynı zamanda, problem kurma etkinliğinde az sayıda problem kuran öğrencinin kendisinden çok daha fazla sayıda problem kuran öğrenciden daha yaratıcı olduğu sonucuna ulaşmış dolayısıyla ortaya atılan fikir sayısından ziyade, fikrin niteliğinin daha önemli olduğunu ortaya koymuştur. Görüldüğü gibi çalışmalar, öğrencilerin problem kurma performanslarındaki yaratıcılıklarının düşüklüğünü genellikle yapılan etkinliklerle ve öğrencilerin problem kurmadaki deneyimsizlikleriyle ilişkilendirmiştir.

Ayrıca literatürde, özgüveni yüksek olan bireylerin problem çözme ve kurma konusunda daha başarılı olduğunu ortaya koyan çalışmalar mevcuttur (Bunar, 2011; Pajares, 1997; Nicolaou \& Philippou, 2007; Özgen \& Bayram, 2019). Özgen ve Bayram (2019), öğrencilerin problem kurma hakkındaki öz yeterliklerinin, problem kurma performansları üzerinde etkili bir faktör olduğunu belirtmiştir. Nicolaou ve Philippou (2007), ortaokul öğrencilerinin problem kurma hakkındaki öz yeterliklerinin problem kurma performanslarının belirleyicisi olduğunu ortaya koymuştur. Pajares (1997), öz yeterliği yüksek olan öğrencilerin zorlayıcı bir akademik görevle karşılaştı̆̆ında daha sakin ve soğukkanlı olduklarını, öz yeterliği düşük olan öğrencilerin ise bu tür görevleri olduğundan daha zor algıladıklarını belirtmiştir. Bundan kaynaklı öğrencilerin streslerinin ve kaygılarının arttığını, probleme yönelik uygun çözümler bulmakta normalinden daha az başarılı olduklarını ortaya koymuştur. Gür ve Korkmaz (2003), öğrencilerin problem kurma becerilerini incelediklerinde problem kurma konusunda kendilerine güvenmeyen öğrencilerin problem kurarken zorluklar yaşadığını ortaya koymuşlardır (Akt: Özgen vd., 2017). Bunar (2011), problem kurmada kendini "başarılı" olarak değerlendirenlerin dolayısıyla problem kurma öz yeterliği yüksek olanların problem kurmada başarılı olduklarını belirtmiştir. Fakat özgüveni yüksek olan öğrencilerin problem kurma konusunda yaratıcı olup olmadığı bilinmemektedir. 
Yine yaratıcılık öz yeterlik ve yaratıcı performans ile ilgili çalışmalar (Choi, 2004; Tierney \& Farmer, 2002;) yaratıcı öz yeterlik eğitimi ile ilgili çalışmalar (Gist 1989; Locke, Frederick, Lee \& Bobko, 1984; Schunk \& Rice, 1987) literatürde mevcuttur. Fakat bu çalışmalarda genellikle yaratıcı öz yeterlik kavramı üzerinde durulmaktadır. Yaratıcılık ve öz yeterlilik ilişkisini problem kurma üzerinde değerlendiren bir çalışmaya rastlanmamıştır. Tüm bunlardan hareketle çalışmanın amacı, ilköğretim 6. Sınıf öğrencilerinin problem kurma yaratıcılıkları ile problem kurma öz yeterlikleri arasındaki ilişkiyi belirlemektir. Bu amaç doğrultusunda araştırmanın ana problemi “İlköğretim 6. sınıf öğrencilerinin kurdukları problemlerin yaratıcılıklarıyla problem kurma konusundaki öz yeterlikleri arasında anlamlı bir ilişki var mıdır?" şeklindedir.

$\mathrm{Bu}$ bağlam içerisinde alt problemler belirlenerek irdelenmiştir:

1. İlköğretim 6. sınıf öğrencilerinin problem kurma yaratıcılıkları ne düzeydedir?

2. İlköğretim 6. sınıf öğrencilerinin kurdukları problemlerin orijinallikleriyle problem kurma konusundaki öz yeterlikleri arasında anlamlı bir ilişki var mıdır?

3. İlköğretim 6. sınıf öğrencilerinin kurdukları problemlerin esneklikleriyle problem kurma konusundaki öz yeterlikleri arasında anlamlı bir ilişki var mıdır?

4. İlköğretim 6. sınıf öğrencilerinin kurdukları problemlerin akıcılıklarıyla problem kurma konusundaki öz yeterlikleri arasında anlamlı bir ilişki var mıdır?

\section{Yöntem}

\section{Araştırma Deseni}

İlköğretim 6. sınıf öğrencilerinin problem kurma yaratıcılıkları ile problem kurma öz yeterlikleri arasındaki ilişkiyi ortaya koymayı amaçlayan bu çalışmada nitel ve nicel yaklaşımlar bir arada ele alınmıştır. Öğrencilerin kurmuş oldukları problemler nitel olarak analiz edilerek problem kurma yaratıcılıkları ortaya koyulmuştur. Öğrencilerin problem kurma yaratıcılık puanları ve problem kurma öz-yeterlikleri puanları arasındaki ilişkiyi ortaya koymak amacıyla da nicel analizler yapılmıştır. Standartlar içerisinde değerlendirmeler yapabilmek ve olayların olası ilişkilerini ortaya koyabilmek için betimsel bir çalışma yaklaşımı benimsenmiştir. Bu bağlamda problem kurma çalışmaları kullanılarak var olan durumun ortaya koyulduğu bu çalışmada tarama yöntemi kullanılmıştır denilebilir. 


\section{Örneklem}

Çalışmanın örneklemi belirlenirken Doğu Karadeniz Bölgesi'nde rastgele iki ilköğretim okulu seçilmiştir. Seçilen ilköğretim okullarının 6. sınıfında öğrenim gören ve gönüllü olarak çalışmaya katılan 123 öğrenci çalışmanın örneklemini oluşturmaktadır. Tarama çalışmaları için örneklemin en az 100 kişiden oluşması gerektiği (Gall, Gall \& Borg, 1989) düşünüldüğünde, örneklem sayısının var olan durumu betimlemek için yeterli olduğu söylenebilir. Çalışmada öğrenciler Ö1, Ö2, ..., Ö123 şeklinde kodlarla ifade edilmiş, öğrenci kimlikleri gizli tutulmuştur. Örneklemin 6. sınıf öğrencilerinden oluşturulmasının sebebi çalışmanın yapıldığı dönem içerisinde kazanımlarının problem kurma etkinlikleri için uygun ve çeşitli olmasıdır. Bu bağlamda amaçlı örneklem seçimi yapılmıştır denilebilir. Araştırmanın yürütüldüğü 2018-2019 eğitim öğretim yılı bahar döneminde çalışmaya katılan tüm öğrenciler öğretim programı gereği problem kurmaya yönelik deneyimlere sahiptir. Örneklemdeki öğrencilerin problem kurmaya dair beklenen geçmiş deneyimlerine yönelik kazanımlar Tablo 1'de verilmiştir.

Tablo 1. Problem kurmaya yönelik kazanımlar

\begin{tabular}{llll}
\hline Sınıf & Öğrenme Alanı & Alt Öğrenme Alanı & Kazanım \\
\hline 6. Sınıf & Sayılar ve İşlemler & Doğal Sayılarla İşlemler & $\begin{array}{l}\text { M.6.1.1.4. Doğal sayılarla dört işlem } \\
\text { yapmayı gerektiren problemleri çözer } \\
\text { ve kurar. }\end{array}$ \\
\hline 6. Sınıf & Sayılar ve İşlemler & Kesirlerle İşlemler & $\begin{array}{l}\text { M.6.1.5.2. Kesirlerle toplama ve çıkarma } \\
\text { işlemlerini yapar. }\end{array}$ \\
\hline 6. Sınıf & Sayılar ve İşlemler & Kesirlerle İşlemler & $\begin{array}{l}\text { M.6.1.5.3. Bir doğal sayı ile bir kesrin } \\
\text { çarpma işlemini yapar ve anlamlandırır. }\end{array}$ \\
\hline 6. Sınıf & Sayılar ve İşlemler & Kesirlerle İşlemler & $\begin{array}{l}\text { M.6.1.5.4. İki kesrin çarpma işlemini } \\
\text { yapar ve anlamlandırır. }\end{array}$ \\
\hline 6. Sınıf & Sayılar ve İşlemler & Kesirlerle İşlemler & $\begin{array}{l}\text { M.6.1.5.8. Kesirlerle işlem yapmayı } \\
\text { gerektiren problemleri çözer. }\end{array}$ \\
\hline 6. Sınıf & Geometri ve Ölçme & Alan Ölçme & $\begin{array}{l}\text { M.6.3.2.5. Alan ile ilgili problemleri } \\
\text { çözer. }\end{array}$ \\
\hline
\end{tabular}

Tablo 1'den görüldüğü gibi öğretim programında problem kurma etkinliklerinin işe koşulması beklenen kazanımlar alt öğrenme alanı bakımından çeşitlidir. Öğrencilerin “Doğal Sayılarla İşlemler, Kesirlerle İşlemler, Alan Ölçme” alt öğrenme alanlarında problem kurma deneyimlerinin mevcut olması beklenmektedir. 
Öğrencilerinin problem kurma hakkındaki öz yeterliklerini tespit etmek için Özgen ve Bayram (2019) tarafından geliştirilen Problem Kurma Öz Yeterlik Ölçeği kullanılmıştır. Ölçeğe ait faktör analizleri sonucunda ölçeğin 5 faktör içerdiği bilinmektedir. Faktörler için bütüncül varyans yüzdesi \%45,64' tür. Ölçeğe ait Cronbach alfa iç tutarlılık güvenirlik katsayısı $0.85^{\prime}$ tir. Ölçek 5'li Likert tipindedir ve 24 maddeden oluşan bir ölçektir. Ölçek “kesinlikle katılıyorum", "katılıyorum", "kararsızım”, “katılmıyorum” ve "kesinlikle katılmıyorum" seçeneklerinden oluşmaktadır. Ölçek maddelerinin 7'si olumsuz ve 17'si olumludur. Bu ölçekteki olumlu maddelerin puanları 5-4-3-2-1 şeklindeyken olumsuz maddelerin puanları 1-2-3-4-5 şeklindedir. Ölçek sonucunda en düşük 24 puan alınabilirken en yüksek 120 puan alınabilmektedir. Alınan yüksek puanlar problem kurma hakkındaki güçlü öz yeterlik inançlarını gösterirken, düşük puanlar ise problem kurma hakkındaki zayıf öz yeterlik inançlarını göstermektedir.

Öğrencilerinin problem kurmaya yönelik yaratıcılıklarını belirlemek için yapılandırılmamış problem kurma çalışmaları yürütülmüştür. Çünkü yapılandırılmamış problem kurma durumları, öğrencilerin problem kurma yaratıcılıklarını sade bir şekilde, her yönüyle gözlemleyebilmeyi sağlamaktadır (Bayazit \& Kırnap-Dönmez, 2017). Ayrıca onlardan olay ya da durumlardan yararlanarak problemler kurmaları istendiğinden öğrenciler problemlerin verilenlerini, istenenlerini ve soru cümlesini kendileri oluşturur. Bu tarz etkinliklerde hayal etmek ve yaratıcı düşünmek ön safhadadır (Özgen vd., 2017). Problem kurma çalışmaları tasarlanırken, matematik dersi öğretim programında (Millî Eğitim Bakanlığı [MEB], 2018) yer alan kazanımlar incelenerek problem kurmaya uygun kazanımlar belirlenmiştir. İki araştırmacı ve bir alan uzmanı en uygun 6 kazanımı belirlemiştir. Bu doğrultuda araştırmacılar tarafından üç adet yapılandırılmamış problem kurma etkinlikleri tasarlanmıştır. Tasarlanan etkinlikler bir alan uzmanı tarafından incelenmiş, konu ve kapsam geçerliliği ayrıca da yapılandırılmamış problem kurma faaliyetlerine uygunluğu değerlendirilmiştir. Uzman görüşü sonrasında etkinliklere son hali verilmiştir. Etkinliklerin amaca uyguluğunu belirlemek için 20 kişiden oluşan bir grupla pilot problem kurma çalışmaları yürütülmüş ve etkinlikler revize edilmiştir. Problem kurma yaratıcılıklarının belirlenmesi amacı ile geliştirilen yapılandırılmamış problem kurma etkinlikleri ve uygun oldukları kazanımlar Tablo 2' de yer almaktadır. 
Tablo 2. Etkinlikler ve kazanımlar

\begin{tabular}{|c|c|}
\hline Etkinlik & Kazanım \\
\hline $\begin{array}{l}\text { - İçinde doğal sayılarla dört } \text { işlemi } \\
\text { kullanabileceğiniz bir problem kurunuz. }\end{array}$ & $\begin{array}{l}\text { M.6.1.1.4. Doğal sayılarla dört işlem yapmayı } \\
\text { gerektiren problemleri çözer ve kurar. }\end{array}$ \\
\hline $\begin{array}{l}\text { - İçinde kesirlerde toplama, çıkarma, çarpma } \\
\text { kullanabileceğiniz bir problem kurunuz. (Kesir } \\
\text { modelleri kullanmakta serbestsiniz.) }\end{array}$ & $\begin{array}{l}\text { M.6.1.5.2. Kesirlerle toplama ve çıkarma işlemlerini } \\
\text { yapar. } \\
\text { M.6.1.5.3. Bir doğal sayı ile bir kesrin çarpma } \\
\text { işlemini yapar ve anlamlandırır. } \\
\text { M.6.1.5.4. İki kesrin çarpma işlemini yapar ve } \\
\text { anlamlandırır. } \\
\text { M.6.1.5.8. Kesirlerle işlem yapmayı gerektiren } \\
\text { problemleri çözer. }\end{array}$ \\
\hline $\begin{array}{l}\text { - İçinde üçgenleri, dikdörtgenleri ve } \\
\text { paralelkenarları kullanabileceğiniz bir problem } \\
\text { kurunuz. (Birleşik } \quad \text { şekiller } \quad \text { kurmakta } \\
\text { serbestsiniz.) }\end{array}$ & M.6.3.2.5. Alan ile ilgili problemleri çözer. \\
\hline
\end{tabular}

Etkinliklerde öğrencilere sadece bağlam ve matematiksel konu verilmiş, öğrencilerin ne doğrultuda problem kuracaklarına müdahale edilmemiştir. Yapılandırılmamış problem kurma etkinliklerinde öğrencilere problem verilmeden, bağlamda bir sınırlandırma olmadan verilen doğal duruma uyacak problemler kurmaları beklenir (Kar \& Işık, 2015). Bu bağlamda etkinliklerin yapılandırılmamış problem kurma etkinliklerinin doğasına uygun olduğu söylenebilir.

\section{Veri Toplama Süreci}

Veri toplama sürecine başlamadan önce öğrencilerle uygun oldukları bir zaman dilimi belirlenmiştir. Öğrencilerin uygunluk durumlarına göre dört farklı grup oluşturulmuş ve ön görüşme yapılmıştır. Öğrenciler çalışmanın amacı, gerçekçi cevap vermelerinin önemi ve cevaplarının not olarak değerlendirilmeyeceği hakkında bilgilendirilmiştir. Öncelikle öğrencilere Problem Kurma Öz Yeterlik Ölçeği uygulanmıştır. Ölçeği cevaplamak için öğrencilere 40 dakika süre verilmiştir. Öncelikle Problem Kurma Öz Yeterlik Ölçeği'nin uygulanmasının sebebi öğrencilerin problem kurma sürecinde yaşadıklarından etkilenmelerini önlemeye çalışmaktır. Çünkü, problem kurma sürecinde yeterli olduğunu düşünen bir öğrenci problem kurma sürecinde zorlandığını fark edip ölçek maddelerine buna göre cevap verirse çalışma sonuçları olumsuz etkilenecektir. Ölçek uygulandıktan bir hafta sonra aynı öğrencilere yapılandırılmamış problem kurma etkinlikleri uygulanmıştır. 
Öğrencilere etkinlikler yazılı olarak verilmiş ve bu doğrultuda yazılı olarak cevaplamaları istenmiştir. Bunun için de öğrencilere 40 dakika süre verilmiştir.

\section{Verilerin Analizi}

Öğrencilerin problem kurma öz yeterliklerinin belirlenmesi amaciyla Problem Kurma Öz Yeterlik Ölçeği'ne verdikleri cevaplar puanlanmış ve her öğrenci için toplam öz yeterlilik puanı belirlenmiştir. Puanlama kullanılan ölçeğin geliştirilme sürecinde tanıtılan şekilde yürütüldügünden analiz güvenirliliği için herhangi bir çalışmaya gerek görülmemiştir.

Öğrencilerin kurdukları problemlerin yaratıcılıkları Amaral ve Carreira (2013) tarafından geliştirilen Taşkın (2016) tarafından revize edilen teorik yapı dikkate alınarak nitel olarak analiz edilmiştir. Öğrencilerin kurdukları problemler Tablo 3'de verilen teorik yapı kullanılarak detaylı bir şekilde incelenmiş ve yaratıcılık puanları hesaplanmıştır.

Tablo 3. Problem Kurma Çalışması Kapsamında Kurulan Problemlerin Yaratıcılık Analizinde Kullanılan Teorik Yapı (Taşkın, 2016)

\begin{tabular}{ll}
\hline Kod & Açıklayıcılar \\
\hline & 1) Özgün diyagramlar, tablolar, şekiller, vb. oluşturur ve bunların yorumlanmasına yönelik \\
problem kurar.
\end{tabular}

Yaratıcılık puanlarının hesaplanmasında bu teorik yapının kullanılmasının sebebi yaratıcılık göstergelerinin ayrı ayrı ele alınarak açıklayıcıların net bir şekilde ortaya koyulmuş olmasıdır. Bu teorik yapıya göre puan hesaplaması şu şekildedir.

Orijinallik puanı (O): Öğretmen adaylarının kurduğu problemdeki orijinallik göstergesine ait rastlanan her açıklayıcı için 10 puan verilir, elde edilen toplam puan, üçe bölünür (3 açıllayıcı mevcuttur.). 
Esneklik puanı (E): Öğretmen adaylarının kurduğu problemdeki esneklik göstergesine ait rastlanan her açıklayıcı için 10 puan verilir, elde edilen toplam puan, beşe bölünür (5 açıklayıcı mevcuttur.).

Akıcılık puanı (A): Öğretmen adaylarının kurduğu problemdeki akıcılık göstergesine ait rastlanan her açıklayıcı için 10 puan verilir, elde edilen toplam puan, dörde bölünür (4 açıllayıcı mevcuttur.).

Yaratıcılık puanı: Hesaplanan orijinallik, akıcılık, esneklik puanlarının toplamından elde edilir. Bu şekildeki bir puanlama ile öğrenci bir problemden 10 esneklik, 10 orijinallik, 10 akıcllık olmak üzere en fazla 30 puan, en az 0 puan alabilir. Çalışmada öğrencilerden 3’er problem kurmaları istenmiştir. Kurulan problemlerin niceliğinin sınırlandırılma nedeni niteliği ön plana çıkarmaktır. Buradan yola çıkarak 3 problem kurma faaliyeti yürütüldüğünden toplamda en fazla 90 puan, en az 0 puan alınabilir.

Öğrencilerin problem kurma etkinliklerinde kurdukları problemler nitelik olarak aynı olmayabilir. Kurulan problemlerin bazıları matematiksel açıdan tam bir yapıya sahip olmayıp eksiklik barındırabilmektedir. Bu yapılan puanlama işlemini etkiler. Çünkü Haavold'a göre (2013) matematikte farklı düşünme görevlerini puanlamak için temel kriterlerden biri matematiksel uygunluktur. Bir problem son derece sıra dışı olabilir ve orijinal olabilir fakat matematiksel olarak da doğru olmalıdır. Bu nedenle problemlerin öncelikle matematiksel ve çözülebilir olup olmadı̆̆ı iki araştırmacı tarafından kontrol edilmiştir. Fikir birliğine varılamadığı durumlarda uzman görüşüne başvurulmuş ve matematiksel olarak çözülebilir problemler belirlenmiştir. Matematiksel olarak doğru olmayan veya matematiksel olarak çözülemeyen problemler (dolayısıyla bu problemleri kuran öğrenciler) çalışmaya dâhil edilmemiştir. Bu bağlamda çalışmaya 148 öğrenci katılmış, 25 öğrencinin kurduğu problemler belirtilen kriterleri sağlamadığı için bu öğrenciler çalışmaya dâhil edilmemiştir. Başka bir deyişle çalışmaya dâhil edilen tüm öğrenciler başarılı şekilde istenilen sayıda problem kurabilmiş öğrencilerdir.

123 öğrencinin kurmuş olduğu problemler, Taşkın'nın (2016) çalışmasında kullandığı yapıdan yola çıkarak elde edilen yapıyla değerlendirilmiştir. Bu yapıda matematiksel olarak çözülebilen problemlerdeki açıklayıcılar, öğrencinin kurduğu yeni problem önceden kurduğu problemlerden farklı yapıda bir problemse yani önceden kurulan herhangi bir problem ile farklı değişkenler kullanılmış ve problemin çözümü farklı kavram ve prosedürlerin kullanımını gerektiriyor ise 10 puan olarak; öğrencinin kurduğu yeni problem 
önceden kurduğu herhangi bir problem ile çok benzer/aynı yapıda bir problem ise yani önceden kurulan problem ile çok benzer/aynı değişkenler kullanılmış ve problemin çözümü çok benzer/aynı kavram ve prosedürlerin kullanımını gerektiriyor ise 1 puan olarak değerlendirilmiştir. Öğrencilerden üç problem kurmaları istendiğinden, kurdukları farklı yapıdaki problemlerinden en çok 90 puan ve benzer/aynı yapıdaki problemlerinden de en çok 9 puan alabilmişlerdir. Bu puanlandırma yaklaşımı ile kurulan problemlerin akıcılık, esneklik ve orijinallik puanları ayrı ayrı incelenmiştir. Bunlar değerlendirilerek en son aşamada öğrencilerin toplam yaratıcılık puanları belirlenmiştir. Puanlama iki araştırmacı tarafından ortak karar prosedürü ile yürütülmüş böylece analiz güvenirliği sağlanmaya çalışılmıştır. Bu bağlamda iki araştırmacı her öğrencinin oluşturduğu üç problemi de birlikte incelemiş ve teorik yapı doğrultusunda puanlama yapmıştır. Ortak karar verildiği durumlarda öğrencilerin puanları belirlenmiştir. Ortak karara varılamadığı durumlarda ise bir alan uzmanının görüşüne başvurulmuş ve nihai puan belirlenmiş ve öğrencilerin yaratıcılık düzeyleri ortaya koyulmuştur.

Çalışmanın temel problemi gereğince problem kurma yaratıcılıkları ile problem kurma öz yeterlikleri arasındaki ilişki incelenecektir. Bunun için verilerin çözümlenmesinde korelasyon analizi yapılmıştır. Çalışmanın alt problemleri doğrultusunda öğrencilerin kurdukları problemlerin orijinallik, esneklik, akıcılık puanları ile problem kurma öz yeterlik puanları arasındaki ilişkiyi açıklamak amacıyla her ilişki durumu için ayrı ayrı korelasyon analizi yapılmıştır. Verilerin analizinde SPSS 20 paket programı kullanılmıştır. Veri tiplerinin farklı olması farklı korelasyon tekniklerini gerektirdiğinden (Can, 2018) değişken dizilerinin normallik koşulunu sağlayıp sağlamadığı kontrol edilmiş ve koşullar Tablo 4' de gösterilmiştir.

Tablo 4. Normallik Testi Sonuçları

\begin{tabular}{cccc}
\hline & \multicolumn{3}{c}{ Kolmogorov-Smirnov $^{\mathbf{a}}$} \\
\cline { 2 - 4 } & Statistic & df & Sig. \\
\hline Yaratıcılık puanları &, 142 & 123 &, 000 \\
\hline Orijinallik puanları &, 327 & 123 &, 000 \\
\hline Esneklik puanları &, 060 & 123 &, $200^{*}$ \\
\hline Akıcıllk puanları &, 082 & 123 &, 042 \\
\hline Öz-yeterlik puanlar1 &, 090 & 123 &, 016 \\
\hline
\end{tabular}

* Bu değer gerçek anlamlılık değerinin alt sınırıdır. 
Verilerin normallik koşulunu sağlayıp sağlamadığına bakıldığında, Tablo 4'de görülebileceği üzere esneklik puanları $\left(p=, 200^{*}>, 05\right)$ normal dağılım göstermektedir. Yaratıcılık puanları $(\mathrm{p}=, 000<, 05)$, öz yeterlik puanları $(\mathrm{p}=, 016<, 05)$, orijinallik puanları $(\mathrm{p}=$ $, 000<, 05)$ ve akıcılık puanları ( $\mathrm{p}=, 042<, 05)$ ise normal dağılım göstermemektedir (Veri sayısı 30'un üzerinde olduğundan Kolmogorov-Smirnov Testi $[\mathrm{p}>0,05]$ ile incelenmiştir). Aralarındaki ilişkinin sorgulanacağı değişken dizilerinden en az biri normal dağılıma sahip değilse korelasyon analizi tekniklerinden Spearman Korelasyon Analizi kullanılır (Taşpınar, 2017). Bu sonuçlardan yola çıkılarak Spearman Korelasyon Analizi ile korelasyonun belirlenmesi uygun görülmüştür.

\section{Bulgular}

Araştırmada temel olarak "İlköğretim 6. sınıf öğrencilerinin kurdukları problemlerin yaratıcılıklarıyla problem kurma konusundaki öz yeterlikleri arasında anlamlı bir ilişki var mıdır?" problemine cevap aranmaktadır. Elde edilen bulgular alt problemler bağlamında ele alınmıştır.

\section{Öğrencilerin Problem Kurma Yaratıcılıklarına Yönelik Bulgular}

$\mathrm{Bu}$ bağlamda öncelikle öğrencilerin problem kurma yaratıcılıkları belirlenmiştir. Öğrenciler ilk olarak "İçinde doğal sayılarla dört işlemi kullanabileceğiniz bir problem kurunuz." yönergesine yönelik bir problem kurmaya çalışmıştır. Ö109'un kurmuş olduğu problem Şekil 2'de verilmiştir.

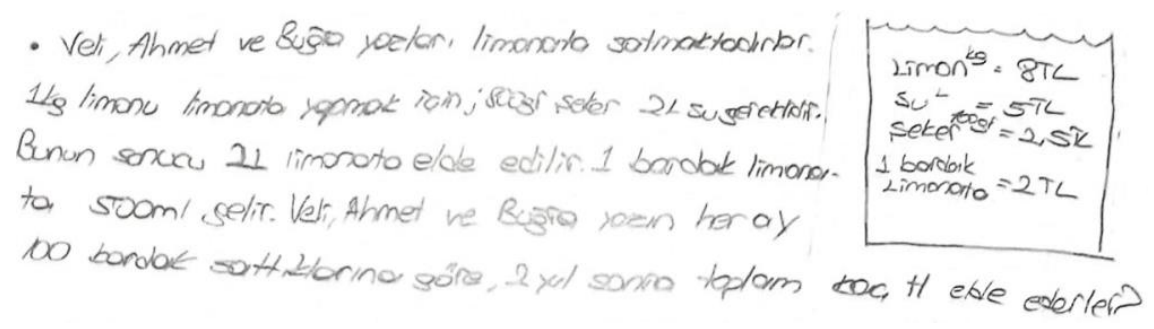

Şekil 2. Ö109'un kurmuş olduğu ilk problem

Ö109'un kurmuş olduğu bu problem 2 yıl boyunca yapılan limonata satışından elde edilecek gelir ile ilgilidir. Kurulan problem orijinallik açısından incelendiğinde probleme ait olan bazı verilerin listelenerek verilmesinin mevcut verilere farklı bir bakış açısı getirdiği görülmektedir. Burada orijinallik göstergelerinden üçüncü maddenin açığa çıktığ görülmektedir. Probleminde bir liste oluşturulsa da liste yorumlamayı gerektiren bir durumdan ziyade verilerin sunumunu değiştirmektedir. Ayrıca problemin çözümünde sıra dışı stratejilerin kullanılmasını gerektiren bir durum yoktur. Bu bağlamda orijinallik 
göstergelerinden sadece üçüncü göstergeden puan almış, birinci ve ikinci göstergeden puan alamamıştır. Birinci problem için öğrencinin nihai orijinallik puanı 10/3=3,33 puandır. Problem esneklik açısından incelendiğinde, esnekliğin birinci, ikinci ve üçüncü maddelerinin açığa çıktığı görülmektedir. Çünkü ml, yıl, kg vs. gibi farklı değişkenler kullanılmıştır. Birden fazla yolla ve işlem öncelikleriyle çözülebilecek bir problemdir. Aynı zamanda verilen değişkenler birbirleriyle, limonata yapma ve satma amacına uygun olarak ilişkilendirilebilmektedir. Ancak problem tek bir duruma odaklanmakta, farklı durumların incelenmesini gerektirmemektedir. Ayrıca daha önceden kurulan problemlere benzer niteliktedir. Bu bağlamda öğrenci birinci, ikinci, üçüncü göstergelerden 10'ar puan almış, dördüncü ve beşinci göstergeden puan alamamıştır. Öğrencinin bu problem için nihai esneklik puanı 30/5=6 puandır. Problem akıcılık açısından incelendiğinde, akıcılığın birinci, ikinci, üçüncü ve dördüncü maddelerinin açığa çıktığı görülmektedir. Çünkü belirli işlemlerin kullanılmasını gerektiren, 21 limonata ile $500 \mathrm{ml}$ bardaklar arasındaki ilişkinin keşfedilmesini gerektiren bir problemdir. Aynı zamanda problem ifadesinde kullanılan değişkenler açık ve tutarlı bir şekilde sunulmuştur. Verilen veriler liste yardımıyla düzenlenmiştir. Bu bağlamda öğrenci akıcılığın tüm göstergelerinden 10’ar puan almıştır. Öğrencinin bu problem için nihai akıcılık puanı 40/4=10 puandır. Birinci problem için öğrencinin toplan yaratıcılık puanı ise nihai orijinallik, esneklik ve akıcılık puanlarının toplamı ile hesaplanmıştır. Bu prosedür sonucunda öğrencinin birinci problem kurma faaliyeti için nihai yaratıcılık puanı $3.33+6+10=19,33$ puandır.

Öğrenciler ikinci olarak "İçinde kesirlerde toplama, çıkarma, çarpma kullanabileceğiniz bir problem kurunuz. (Kesir modelleri kullanmakta serbestsiniz.)" yönergesine yönelik bir problem kurmaya çalışmıştır. Ö109'un kurmuş olduğu problem Şekil 3'de verilmiştir.

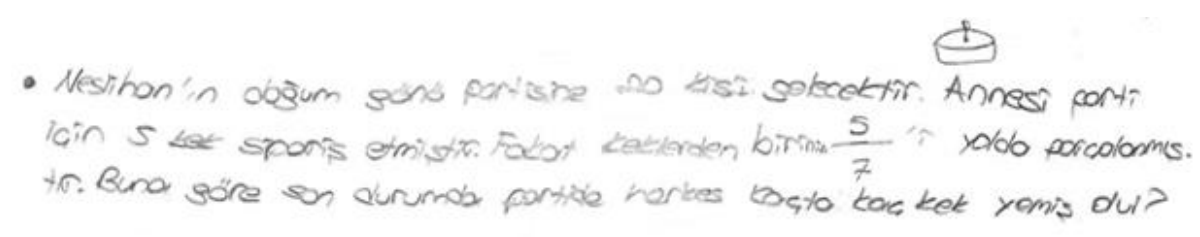

Şekil 3. Ö109'un kurmuş olduğu ikinci problem

Öğrencinin kurmuş olduğu bu problem bir doğum günü için alınan kekin paylaştırılması ile ilgilidir. Problem orijinallik açısından incelendiğinde, orijinalliğin açıklayıcılarının açığa çıkmadığı görülmektedir. Çünkü orijinal diyagramlar, tablolar, şekiller vb., sıra dışı stratejilerin kullanılmasını gerektiren bir sorun, verilere farklı bir bakış 
açısı getirecek bir fikir mevcut değildir. Öğrenci bu problem için orijinallikten 0 puan almıştır. Problem esneklik açısından incelendiğinde, esnekliğin birinci, ikinci, üçüncü ve dördüncü açıklayıcılarının açığa çıktığı görülmektedir. Çünkü kişi sayısı, kek dilimi gibi farklı değişkenler kullanılmıştır. Bu probleme birden fazla çözüm yolu uygulanabilir. Senaryodaki değişkenler birbirleriyle ve kekin paylaştırılması amacına uygun olarak ilişkilendirilmiştir. Senaryodaki değişkenlere göre kekin yolda parçalanan kısmı üzerinden ya da parçalanmamış kısmı üzerinden incelenme yapılabilen bir problem ortaya koyulmuştur. Bu bağlamda esnekliğin birinci, ikinci, üçüncü ve dördüncü açılayıcılarından 10 'ar puan almıştır. Problem önceden derslerde yeri verilen kesir problemlerinin düzenlenmiş bir hali olmaktan ziyade bağlamının değiştirilmiş halidir. Bu bağlamda beşinci açıklayıcı için 0 puan verilmiştir. Öğrencinin bu problem için nihai esneklik puanı 40/5=8 puandır. Problem akıcılık açısından incelendiğinde, akıcılığın birinci, üçüncü ve dördüncü açıklayıcılarının ortaya çıktığı görülmektedir. Problem kesirlerde matematiksel prosedürlerin kullanılmasını gerektiren bir problemdir. Aynı zamanda veriler düzenli bir şekilde sunulmuştur. Bu bağlamda Ö109 akıcılığın birinci, üçüncü ve dördüncü açıklayıcılarından 10'ar puan almıştır. Problem matematiksel kavram ve prosedürlerin geliştirilmesini ve keşfedilmesini gerektirmediğinden akıcılığın ikinci açıklayıcısından puan almamıştır. Öğrencinin bu problem için nihai akıcılık puanı 30/4=7,5 puandır. İkinci problem için öğrencinin toplan yaratıcılık puanı ise nihai orijinallik, esneklik ve akıcılık puanlarının toplamı ile hesaplanmıştır. Bu prosedür sonucunda öğrencinin ikinci problem kurma faaliyeti için nihai yaratıcılık puanı $0+8+7,5=15,5$ puandır.

Öğrenciler üçüncü olarak “İçinde üçgenleri, dikdörtgenleri ve paralelkenarları kullanabileceğiniz bir problem kurunuz. (Birleşik şekiller kurmakta serbestsiniz.)" yönergesine yönelik bir problem kurmaya çalışmıştır. Ö109'un kurmuş olduğu problem Şekil 4'te verilmiştir.

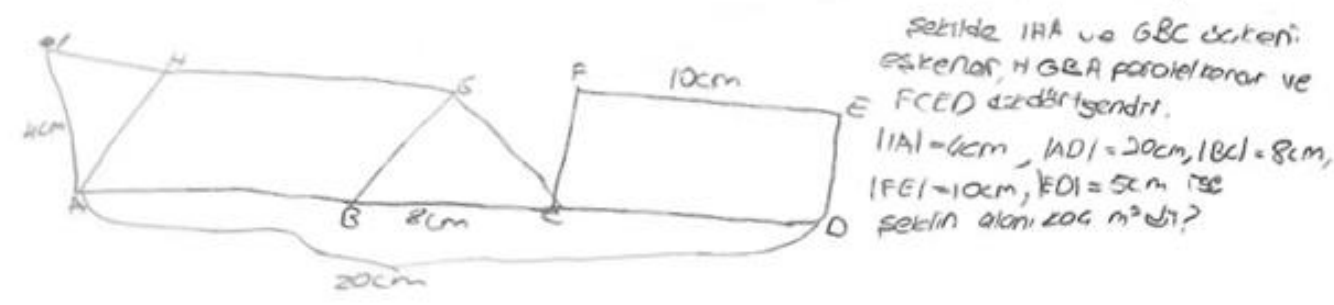

Şekil 4. Ö109'un kurmuş olduğu üçüncü problem 
Öğrencinin oluşturduğu bu problem verilen birleşik bir şeklin alanının bulunması ile ilgilidir. Problem orijinallik açısından incelediğimizde, orijinalliğin birinci ve üçüncü maddelerinin açı̆̆a çıktığı görülmektedir. Çünkü problemde öğrenci kendi bileşik şeklini oluşturmuştur. Aynı zamanda eşkenar üçgenlere, paralelkenara vs. farklı bir bakış açısı getirerek alan hesaplanmasını istemiştir. Bu bağlamda orijinalliğin birinci ve üçüncü açıklayıcılarından 10'ar puan almıştır. Ancak problem özgün ve sıra dışı stratejilerin kullanılmasını gerektirmekten ziyade bilindik yaklaşımlarla alan hesaplamasını gerektirmektedir. Bu bağlamda orijinalliğin ikinci açıklayıcısından puan verilmemiştir. Bu problem için öğrencinin nihai orijinallik puanı 20/3=6,67 puandır. Problem esneklik açısından incelendiğinde, esnekliğin ikinci ve beşinci açıklayıcılarının açığa çıktığ görülmektedir. Çünkü problemde birleşik şekiller açısından farklı alan hesaplamaları planlanarak farklı çözüm yolları kullanılabilir. Öğrenci daha önce ayrı ayrı ele alınan alanları yeniden düzenleyerek bu problemi oluşturmuştur. Bu bağlamda ikinci ve beşinci açıklayıcılardan 10'ar puan almıştır. Problem farklı değişkenler içermemekte, dolayısıyla farklı değişkenler arası ilişkilerin kurulmasına gerek duyulmayan ve değişkenlere yönelik farklı durumların incelenmesini gerektirmeyen bir problemdir. Bu bağlamda problem için esnekliğin birinci, üçüncü ve dördüncü açılayıcılarından 0 puan verilmiştir. Öğrencinin bu problem için nihai esneklik puanı 20/5=4 puandır. Problem akıcılık açısından incelendiğinde, akıcılığın birinci ve ikinci açıklayıcılarının açığa çıktığı görülmektedir. Çünkü matematiksel prosedürlerin kullanılmasını gerektiren ve eşkenar çokgenlerin özellikleri gibi bilgilerin geliştirilmesini gerektiren bir problem kurmuştur. Problem ifadesinde kullanılan dikdörtgenin adlandırılması yanlış yapılmıştır bu nedenle açı ve tutarlı değildir. Veriler düzenlenme yoluyla iletişim kurmaya uygun değildir. Bu bağlamda Ö109 akıcılığın birinci ve ikinci açıklayıcılarından 10 'ar puan, üçüncü ve dördüncü açıklayıcılarından 0 puan almıştır. Öğrencinin bu problem için nihai akıcılık puanı 20/4=5 puandır. Üçüncü problem için öğrencinin toplan yaratıcılık puanı ise nihai orijinallik, esneklik ve akıcılık puanlarının toplamı ile hesaplanmıştır. Bu prosedür sonucunda öğrencinin ikinci problem kurma faaliyeti için nihai yaratıcılık puanı $6,67+4+5=15,67$ puandır.

Ö109'un genel orijinallik, esneklik, akıcılık ve yaratıcılık puanlarının belirlenebilmesi için her problem için almış oldukları puanlar dikkate alınarak toplam puanları hesaplanmıştır. Puanların özeti tablo 5'te verilmiştir. 
Tablo 5. Ö109'un orijinallik, esneklik, akıcılık ve yaratıcılık puanları

\begin{tabular}{ccccc}
\hline & $\begin{array}{c}\text { Orijinallik puanı } \\
\text { (min 0 puan-max } \\
\text { 30 puan) }\end{array}$ & $\begin{array}{c}\text { Esneklik puanı } \\
\text { (min 0 puan-max } \\
\text { 30 puan) }\end{array}$ & $\begin{array}{c}\text { Akıcılık puanı } \\
\text { (min 0 puan- } \\
\text { max 30 puan) }\end{array}$ & $\begin{array}{c}\text { Yaratıcılik puanı } \\
\text { (min 0 puan-max } \\
\text { 90 puan) }\end{array}$ \\
\hline $\begin{array}{c}\text { 1.Problem kurma } \\
\text { etkinliği }\end{array}$ & 3,33 & 6 & 10 & 19,33 \\
\hline $\begin{array}{c}\text { 2.Problem kurma } \\
\text { etkinliği }\end{array}$ & 0 & 8 & 7,5 & 15,5 \\
\hline $\begin{array}{c}\text { 3.Problem kurma } \\
\text { etkinliği }\end{array}$ & 6,67 & 4 & 5 & 15,67 \\
\hline Toplam & 10 & 18 & 12,5 & 50,5 \\
\hline
\end{tabular}

Her öğrenci için benzer prosedür ile orijinallik, esneklik, akıcılık ve yaratıcılık puanları hesaplanmıştır. Çalışmada ele alınan problem kurma yaklaşımları benzer nitelikte olduğundan her problem kuma faaliyeti için ortalama puanları bilmek yerine genel ortalamayı bilmek daha anlamlı olacaktır. Bu bağlamda yukarıda sadece analize örnek olması açısından katılımcılar arasından rastgele seçilen Ö109'un her problem kurma faaliyetine yönelik puanları verilmiştir. İlerleyen bölümde genel orijinallik, esneklik, akıcılık ve yaratıcılık puanlarına yönelik ortalamalar incelenmiştir. Ayrıca öz-yeterlilik ölçeğinden alınan puanlar da hesaplanmıştır. Çalışmaya katılan öğrencilerin genel orijinallik, esneklik, akıcılık, yaratıcılık ve öz-yeterlilik puanları Tablo 6' da verilmiştir.

Tablo 6. Öğrencilerin orijinallik, esneklik, akıcılık, yaratıcılık ve öz-yeterlilik puan ortalamaları

\begin{tabular}{|c|c|c|c|c|c|}
\hline & $\begin{array}{l}\text { Orijinalli } \\
\text { k puanı } \\
\text { (min } 0 \\
\text { puan-max } \\
30 \text { puan) }\end{array}$ & $\begin{array}{c}\text { Esneklik } \\
\text { puanı } \\
\text { (min } 0 \\
\text { puan-max } \\
30 \text { puan) }\end{array}$ & $\begin{array}{c}\text { Akıcılık } \\
\text { puanı } \\
\text { (min } 0 \\
\text { puan-max } \\
30 \text { puan) }\end{array}$ & $\begin{array}{c}\text { Yaratıcılık } \\
\text { puanı } \\
\text { (min } 0 \text { puan- } \\
\text { max } 90 \\
\text { puan) }\end{array}$ & $\begin{array}{c}\text { Özyeterlilik } \\
\text { puanı } \\
\text { (min } 24 \text { puan- } \\
\text { max } 120 \text { puan) }\end{array}$ \\
\hline Puan ortalamaları & 8,37 & 10,51 & 13,01 & 31,90 & 90,56 \\
\hline
\end{tabular}

Tablo 6 incelendiğinde en düşük puan ortalamasına sahip bileşenin orijinallik bileşeni olduğu, en yüksek puan ortalamasına sahip bileşenin ise akıcılık bileşeni olduğu, ancak yine de öğrencilerin orijinallik, esneklik, akıcılık ve genel yaratıcılık puanlarının oldukça düşük olduğu görülmektedir. Problem kurmaya yönelik öz-yeterliklerinin ise yükseğe yakın olduğu görülmektedir.

Öğrencilerin Problem Kurma Öz Yeterlikleri ile Problem Kurma Yaratıcılıkları Arasındaki İlişkiye Yönelik Bulgular

Araştırmanın diğer problemlerine cevap vermek amacıyla öğrencilerin orijinallik, esneklik, akıcılık, yaratıcılık ve öz-yeterlilik puanları arasındaki ilişkiyi belirleyebilmek için 
korelasyon analizi yapılmıştır. Puanlar karşılaştırılırken anlamlılık düzeyi 0,05 olarak kabul edilmiştir. Sonuçlar Tablo 7' de verilmiştir.

Tablo 7. Orijinallik, esneklik, akıcılık, yaratıcılık ve öz-yeterlilik puanları Arasındaki korelasyon analizi

\begin{tabular}{|c|c|c|c|c|c|c|}
\hline & & & Orijinallik & Esneklik & Akıcılık & Yaratıcılık \\
\hline \multirow{3}{*}{ Spearman's rho } & \multirow{3}{*}{ Öz Yeterlik } & $\begin{array}{l}\text { Correlation } \\
\text { Coefficient } \\
\end{array}$ &, $184^{*}$ &, $194^{*}$ & , $180^{*}$ & 132 \\
\hline & & Sig. (2-tailed) & ,042 & , 032 & ,046 & , 146 \\
\hline & & $\mathrm{N}$ & 123 & 123 & 123 & 123 \\
\hline
\end{tabular}

Tablo 7'te de görüldüğü gibi öğrencilerin kurdukları problemlerin orijinallik puanları ile problem kurma öz yeterlik puanları arasında istatistiksel olarak anlamlı ilişki olduğu görülmektedir $\left(r=0,180^{*} ; \mathrm{p}=0,046\right)$. Bu bulgularından, aradaki ilişkinin pozitif yönde anlamlı ve düşük düzeyde olduğu söylenebilmektedir. Tablo incelendiğinde öğrencilerin kurdukları problemlerin esneklik puanları ile problem kurma öz yeterlik puanları arasında istatistiksel olarak anlamlı ilişki bulunmuştur $\left(r=0,194^{*} ; \mathrm{p}=0,032\right)$. Bu bulgularından, aradaki ilişkinin pozitif yönde anlamlı ve düşük düzeyde olduğu söylenebilmektedir. Öğrencilerin kurdukları problemlerin akıcılık puanları ile problem kurma öz yeterlik puanları arasındaki ilişki incelendiğinde, bu iki değişken arasında istatistiksel olarak anlamlı ilişki olmadığı görülmektedir $(r=0,132 ; p=0,146)$. Korelasyon analizi sonuçları incelendiğinde, öğrencilerin problem kurma yaratıcılık puanları ile problem kurma öz yeterlik puanları arasında istatistiksel olarak anlamlı ilişki bulunmuştur $\left(r=0,184^{*} ; \mathrm{p}=0,042\right)$. Bu bulgularından, ilişkinin pozitif yönde anlamlı ve düşük düzeyde olduğu söylenebilmektedir.

\section{Tartışma ve Sonuç}

Çalışma sonucunda öğrencilerin en düşük puan ortalamasına sahip oldukları bileşenin orijinallik bileşeni olduğu, en yüksek puan ortalamasına sahip oldukları bileşenin ise akıcılık bileşeni olduğu, ancak yine de öğrencilerin orijinallik, esneklik, akıcılık ve genel yaratıcılık puanlarının oldukça düşük olduğu görülmüştür. Yapılan çalışmalar mevcut çalışma sonuçlarına benzer şekilde öğrencilerin problem kurma performanslarında yaratıcılıklarının düşük (Arıkan, 2013; Bayazit \& Kırnap-Dönmez, 2017; Çetinkaya \& Soybaş, 2018; Korkmaz \& Gür, 2006; Özgen vd., 2017; Şengül \& Katranc1, 2012; Taşkın, 2016; Tertemiz \& Sulak, 2013) olduğunu ortaya koymaktadır. Taşkın (2016), öğrencilerin kurdukları problemleri incelediğinde özellikle özgünlük açısından yetersiz olduğunu ortaya 
koymuştur. Korkmaz ve Gür (2006) matematik öğretmeni adaylarının da benzer tipte problem kurduklarını ifade etmektedir. Buradan öğretmen adaylarının da kurdukları problemlerin özgün olmadığı söylenebilir. Özgün problem kurmanın hem öğrenciler hem de öğretmen adayları için zor olduğu ifade edilebilir. Bunun nedeni öğrencilerin derslerde çoğunlukla problem çözme faaliyetlerinde yer almış olmaları veya deneyimledikleri problem kurma faaliyetlerinin problemlere benzer problemler kurma yönünde olması olabilir. Tertemiz ve Sulak (2013), öğrencilerin problem kurarken yeni bir bilgi eklemek, konuyu değiştirmek ve koşulları değiştirmek gibi üst düzeydeki becerileri işe koşamadıklarını ifade etmektedir. Bu çalışmada da öğrencilerin esneklik puanlarının oldukça düşük olduğu görülmüştür. Bu bağlamda çalışma sonucunun Tertemiz ve Sulak (2013) çalışmasıyla paralellik gösterdiği görülmektedir. Öğrencilerin yapılandırılmamış problem kurma faaliyetleri gibi özgünlük ve yaratıcılık isteyen etkinliklerde başarısız oldukları (Bayazit \& Kırnap-Dönmez, 2017; Çetinkaya \& Soybaş, 2018; Özgen vd., 2017) bilinmektedir. Her ne kadar yapılandırılmamış problem kurma durumları, öğrencilerin problem kurma yaratıcılıklarını sade bir şekilde, her yönüyle gözlemleyebilmeye imkan sağlasa da (Bayazit \& Kırnap-Dönmez, 2017), olay ya da durumlardan yararlanarak problemler kurmaları istendiğinde problemlerin verilenlerini, istenenlerini ve soru cümlesini kendileri oluştursalar da, bu tür faaliyetlerde hayal etmek ve yaratıcı düşünmek ön safha (Özgen vd., 2017) olsa da öğrenciler bu konuda deneyime sahip değillerse yaratıcı olmaktan ziyade bir problem kurabilmeye odaklanabilir ve problem kurma yaratıcılıkları olumsuz yönde etkilenebilir. Yani yapılandırılmamış problem kurma faaliyetlerinin avantajları dezavantaja dönüşebilir. $\mathrm{Bu}$ bağlamda bu çalışmada yapılandırılmamış problem kurma yaklaşımının kullanılmasının öğrencilerin orijinallik, esneklik, akıcılık ve genel yaratıcılık puanlarının düşük olmasını etkileyen bir sebep olarak görülmektedir.

Öğrencilerin kurdukları problemlerin orijinallikleriyle problem kurma konusundaki öz yeterlikleri arasında istatistiksel olarak anlamlı ve düşük düzeyde bir korelasyon olduğu sonucuna ulaşılmıştır. Kesgin (2006), öz yeterliliği düşük olan kişilerin tüm konulara sınırlı bir gözle baktı̆̆ını ve dolayısıyla orijinal olamadıklarını belirtmiştir. Taşkın (2016), öğrencilerin kurdukları problemleri incelediğinde özellikle özgünlük açısından yetersiz olduğunu ortaya koymuştur. Aynı zamanda, orijinalliğin öğrencilerin problem kurma faaliyetlerine aşina olmalarıyla ve kendilerini bu konuda yeterli görmeleriyle ilgili olduğunu belirtmiştir. Bunlardan yola çıkarak öğrencilerin kurdukları problemlerin orijinalliklerinin 
problem kurma konusundaki öz yeterlikleriyle ilişkili olduğu sonucu Kesgin'in (2006) çalışmasıyla örtüşmektedir ve literatürden farklı olarak ilişkinin varlığı istatistiksel olarak da ortaya koyulmaktadir.

Öğrencilerin kurdukları problemlerin esneklikleriyle problem kurma konusundaki öz yeterlikleri arasında istatistiksel olarak anlamlı ve düşük düzeyde bir korelasyon olduğu sonucuna ulaşılmıştır. Öz yeterliliği düşük olan bireyler olayların olduğundan zorlayıcı olduğunu düşünerek (Kesgin, 2006), farklı konularda da düşünmeye istekli ve motive olamazlar. Dolayısıyla öz yeterliği düşük olan bireylerin esnekliğin göstergeleri olan birden fazla çözüme odaklanmaması, farklı değişkenleri işe koşmaması beklenen bir durumdur. Bu ise kurulan problemlerin esnekliğini olumsuz etkilemektedir. Şengül ve Katrancı (2012), öğretmen adaylarının deneyim eksikliklerinden dolayı farklı bakış açılarına sahip olamadıkları dolayısıyla yaratıcı problemler ortaya koyamadıklarını belirtmiştir. Bu görüş de farklı bakış açılarının probleme yansıtılamadığını, dolayısıyla problemlerin esnekliğinin etkilendiğini göstermektedir. Bayazit ve Kırnap-Dönmez (2017), öğretmen adaylarının kurdukları problemleri incelediğinde yapılandırılmamış problem kurma etkinliklerinde yaratıcılığın azaldığını çünkü bu etkinliklerin sadece genel bir bağlam böylece yüksek düzeyde muhakeme, hayal gücü, yaratıcılık kullanmanın öğrenciler için zorlayıcı olduğunu belirtmiş ve bu durumun düşüncenin doğası gereği olduğunu aynı zamanda bilginin içeriğinden kaynaklandığını belirtmiştir. Bu vurgu da yapılandırılmamış problem kurma etkinliklerinde esnekliğin düşük olabileceğine işaret etmektedir. Dolayısıyla problem kurma konusundaki öz yeterliklerinin kurulan problemlerin esnekliği ile ilişkili olduğu sonucu diğer çalışmalarla örtüşmektedir ve literatürden farklı olarak ilişkinin varlığı istatistiksel olarak ortaya koyulmuştur.

Öğrencilerin kurdukları problemlerin akıcılıklarıyla problem kurma konusundaki öz yeterlikleri arasında istatistiksel olarak anlamlı bir ilişki olmadığı sonucuna ulaşılmıştır. Leikin (2009) akıcılığın değişken ve geliştirilebilir bir yapıya sahip olduğunu belirtirken, Taşkın (2016) öğrencilerin çok sayıda benzer problem kurmasının akıcılık puanlarını yükselttiğini belirtmiştir. Aynı zamanda Taşkın (2016), problem kurma etkinliğinde az sayıda problem kuran öğrencinin kendisinden çok daha fazla sayıda problem kuran öğrenciden daha yaratıcı olduğu sonucuna ulaşmış dolayısıyla ortaya atılan fikir sayısından ziyade, fikrin niteliğinin daha önemli olduğunu ortaya koymuştur. Bu çalışmada öğrencilerden verilen yönergelere yönelik birer problem kurmaları istenmiştir. Bu nedenle 
kurulan problemlerin niceliği sınırlandırılmış, niteliği ön plana çıkarılmaya çalışılmıştır. Benimsenen analiz yaklaşımı da bu duruma uygun şekildedir. Dolayısıyla öğrencilerin akıcılıklarının düşük çıkması kurulan problemlerin niteliği ile ilgilidir. Akıcılık göstergesi matematiksel kavramların geliştirilmesine ve yeni prosedürlerin keşfedilmesine yönelik kaynaklardan beslendiğinden genel olarak öğrencilerin kurdukları problemlerdeki akıcılıkların düşük olması beklenen ve benzer yaklaşımın benimsediği literatürce (Taşkın, 2016) ortaya koyulan bir durumdur. Değişkenler arası ilişkinin olmayışı da bu sebepten kaynaklı olabilir.

$\mathrm{Bu}$ araştırmada ilköğretim 6. sınıf öğrencilerinin problem kurma öz yeterlikleri ile yaratıcılıkları arasındaki ilişki incelenmiştir. Elde edilen bulgulara göre öğrencilerin kurdukları problemlerin yaratıcılıklarıyla problem kurma konusundaki öz yeterlikleri arasında istatistiksel olarak anlamlı ve düşük düzeyde bir korelasyon olduğu sonucuna ulaşılmıştır. Bu sonuçtan yola çıkarak, öğrenciler mevcut bilgi ve becerilerine güvenerek yeni fikirler üretmek için istek duyarlarsa yaratıcılık konusunda başarılı ürünler ortaya koyabilirler; benzer şekilde yaratıcılık konusunda başarılı ürünler ortaya koyabilen öğrenciler de mevcut bilgi ve becerilerine güvenerek yeni fikirler üretmek için istekli olabilirler denebilir. Yapılan çalışmalar özgüveni yüksek olan bireylerin problem kurma konusunda daha başarılı olduğunu ortaya koymaktadır (Bunar, 2011; Nicolaou \& Philippou, 2007; Özgen \& Bayram, 2019; Pajares, 1997). Ayrıca öğrencilerin problem kurma öz yeterliliğinin geliştirilmesinin, problem kurma performanslarını yükselttiğini ortaya koyan çalışmalar mevcuttur (Bunar, 2011; Nicolaou \& Philippou, 2007). Bu çalışmalar, çalışmada elde edilen sonucu destekler niteliktedir. Farklı olarak bu çalışmada yaratıcılığın problem kurma öz yeterliği ile ilişkili olduğu sonucu da ortaya koyulmuştur. Diğer taraftan Çetinkaya ve Soybaş (2018) öğrencilerin, özgünlük ve yaratıcılık isteyen yapılandırılmamış sorularda ve yapılandırılmamış problem kurma etkinliklerinde başarısız olduklarını ortaya koymuştur. Nicolaou ve Philippou (2007), ortaokul öğrencilerinin problem kurma hakkındaki öz yeterliklerinin problem kurma performansları konusunda belirleyici bir nitelikte olduğunu belirtirken, bazı öğrencilerinin problem kurmaya yönelik öz yeterliklerinin iyi olmasına rağmen problem kurma performanslarının iyi olmadığı sonucuna ulaşmıştır. Bu çalışmada ise başarılı şekilde problem kuramayan öğrenciler çalışmaya dahil edilmemiştir. Dolayısıyla ortaya koyulan sonuç başarılı şekilde problem kurabilen öğrencilerin de öz yeterliklerinin düşük olabileceğini ya da problem kurma öz 
yeterliği düşük olan öğrencilerin de iyi birer problem kurucu olabileceğini göstermektedir. Literatürden farklı olarak ortaya koyulan bu sonuç öğrencileri teşvik eden sosyal ve kültürel faktörlerden kaynaklanmış olabilir.

Çalışma sonuçlarına dayalı olarak şu önerilerde bulunulabilir:

Problem kurma öz yeterliği yüksek olan öğrencilerin problem kurma yaratıcılıklarının da yüksek olduğu ortaya koyulmuştur. Bu konuda öğretmenler, öğrencilerin öz yeterliklerini artıracak dönüt ve pekiştireçler vererek onların yaratıcılığını arttırabilir. Problem kurma öz yeterliği yüksek olan öğrencilerin esnek ve orijinal problemler kurdukları ortaya koyulmuştur. Bu konuda öğretmenler, öğrencilerle yaptıkları problem kurma etkinliklerinde yeni bakış açıları, özgün düşünceler üreten öğrencileri teşvik edebilir ve onlara kendilerini ifade edecekleri etkinlik ortamları sunabilir. Böylece öğrencilerin problem kurmaya yönelik öz yeterlikleri geliştirilebilir. Öğrencilerin problem kurma öz yeterliği yüksek olsa da akıcı problemler kuramadıkları dolayısıyla ortaya çıkan özgün problemlerin sayısının az olduğu ve az sayıda özgün fikir ürettikleri ortaya koyulmuştur. Öğrencilerin birbiri ile benzer fikirler içeren problemler kurdukları görülmüştür. Bu konuda öğretmenler, öğrencilerle problemlerin niteliklerinin de önemli olduğunu gösterecek problem inceleme çalışmaları yapabilir.

$\mathrm{Bu}$ çalışmada her ne kadar öğrencilerin problem kurma yaratıcılıkları ve yaratıcılıkları ile problem kurma-öz-yeterlikleri arasındaki ilişki ortaya koyulmaya çalışılsa da çalışmanın bazı sınırlılıkları mevcuttur. Çalışmanın en önemli sınırlılığı örneklemin problem kurmaya yönelik yaratııılık puanları yapılandırılmamıs problem kurma etkinlikleri kullanılarak ortaya koyulmuş olmasıdır. Yapılan çalışmalar, bireylerin yapılandırılmamış problem kurmakta yarı-yapılandırılmış ve yapılandırılmış problem kurmaya nazaran daha fazla zorlandıklarını ortaya koymuştur. Yaşanan bu zorluğun yaratıcılığı dolayısıyla da esneklik, orijinallik ve akıcılığı etkileyip etkilemediğinin belirlenebilmesi için yapılandırılmamış problem kurma faaliyetleri yerine yarı-yapılandırılmış ve yapılandırılmış problem kurma faaliyetlerini kullanılarak yapılan çalışmadaki sonuçlarla benzer sonuçların ortaya çıkıp çıkmayacağı irdelenebilir. Ayrıca mevcut çalışmada öğrencilerin problem kurma konusundaki öz yeterlikleriyle problem kurmaya yönelik yaratıcılıkları nicel bir yöntem kullanılmıştır. İleride yapılacak çalışmalarda nitel yöntem kullanılarak da bu ilişki ayrıntılı olarak incelenebilir. Böylece değişkenler arası ilişkileri etkileyen faktörler ayrıntılı şekilde araştırılabilir. 
Bilgilendirme

Bu çalışmada kullanılan verilerin 2020 yılı öncesine ait olduğu araştırmacılar tarafından onaylanmıştır. Bu çalışmanın bir bölümü 26-28 Eylül 2019 tarihinde İzmir'de gerçekleştirilmiş olan 4. Uluslararası Türk Bilgisayar ve Matematik Eğitimi (TÜRKBİLMAT-4) Sempozyumunda sözlü bildiri olarak sunulmuştur.

Yazar Katkı Beyanı

Funda AYDIN-GüÇ: Kavramsallaştırma, metodoloji, danışmanlık ve denetim, veri analizi, inceleme-yazma ve düzenleme

Seda KESKIN: Kavramsallaştırma, veri toplama, veri analizi, ön taslak yazımı ve düzenleme

\section{Kaynaklar}

Alkan, R. (2014). Genel yaratıcılı, matematiksel yaratıcılık ve akademik başarı arasındaki ilişkilerin incelenmesi. (Yayımlanmamış Doktora Tezi). Gazi Üniversitesi, Eğitim Bilimleri Enstitüsü, Ankara.

Amaral, N., \& Carreira, S. (2012). An essay on students' creativity in problem solving beyond school: Proposing a framework of analysis. Pre-Proceedings of the International Congress on Mathematical Education (ICME 12) -Topic Study Group, 3, 1584-1593.

Arıkan, E. (2013). İlköğretim 2. sinıf öğrencilerinin matematiksel problem kurma becerilerinin incelenmesi. Amasya Üniversitesi Eğitim Fakültesi Dergisi, 2(2), 305-325.

Bakaç, E., \& Özen, R. (2016). Öğretmen adaylarının öğretim teknolojileri ve materyal tasarımı dersine yönelik tutumları, yaratıcılık algıları ve öz-yeterlik inançları arasındaki ilişki. Abant İzzet Baysal Üniversitesi Ĕ̆gitim Fakültesi Dergisi, 16(1), 41-61.

Balka, D.S. (1974) Creative ability in mathematics. The Arithmetic Teacher, 21(7), 633-636.

Bandura, A. (1997). Self-efficacy: the exercise of control. New york: Freeman.

Bayazit, İ., \& Kirnap-Dönmez, S. M. (2017). Prospective teachers' proficiencies at problem posing in the context of proportional reasoning. Turkish Journal of Computer and Mathematics Education, 8(1), 130-160.

Brunkalla, K. (2009). How to increase mathematical creativity-an experiment. The Montana Mathematics Enthusiast, 6(1), 257-266.

Brown, S.I., \& Walter, M. I. (1990). The art of problem posing. New Jersey: Lawrence Erlbaum Associates, Inc., Publishers.

Budak, İ. (2007). Matematikte üstün yetenekli öğrencileri belirlemede bir model. (Yayımlanmamış Doktora Tezi), Karadeniz Teknik Üniversitesi, Trabzon.

Bunar, N. (2011). Altıncı sını öğrencilerinin kümeler, kesirler ve dört işlem konularında problem kurma ve çözme becerileri. (Yayımlanmamış Yüksek Lisans Tezi). Afyon Kocatepe Üniversitesi, Sosyal Bilimler Enstitüsü.

Can, A. (2018). SPSS ile bilimsel araştırma sürecinde nicel veri analizi. Ankara: Pegem Yayıncılık. 
Chamberlin, S. A., \& Moon, S. M. (2005). Model-eliciting activities as a tool to develop and identify creatively gifted mathematicians. Journal of Secondary Gifted Education, 17(1), 37-47.

Choi, J. N. (2004). Individual and contextual predictors of creative performance: The mediating role of psychological processes. Creativity Research Journal, 16(2-3), 187-199.

Cildir, S., \& Sezen, N. (2011). Skill levels of prospective physics teachers on problem posing. Hacettepe Üniversitesi Ĕ̆itim Fakültesi Dergisi, 40, 105-116.

Çetinkaya, A., \& Soybaş, D. (2018). İlköğretim 8. sınıf öğrencilerinin problem kurma becerilerinin incelenmesi. Kuramsal Ĕ̆itimbilim Dergisi, 11(1), 169-200.

English, L. D. (1997). The development of fifth-grade children's problem- posing abilities. Educational Studies in Mathematics. 34(3), 183-217.

Freire, P. (2018). Pedagogy of the oppressed. Bloomsbury publishing USA.

Gall, M. D., Gall, J. P. \& Borg, W. R.(1989). Educational research: An Introduction. London: Pearson Education.

Gist, M. E. (1989). The influence of training method on self-efficacy and idea generation among managers. Personnel Psychology, 42(4), 787-805.

Gören-Summak, A. E., \& Aydın, Z. (2011). Yaratıcılık ve ulusal eğitim programlarında yaratıcılığa ilişkin araştırmalar. Education Sciences, 6(1), 362-385.

Haavold, P. Ø. (2013). What are the characteristics of mathematical creativity? An emprical and theorical investigation of mathematical creativity? Unpublished Doctoral thesis. University of Tromso, Norway.

Haylock, D. W. (1987). A framework for assessing mathematical creativity in school chilren. Educational Studies in Mathematics, 18(1), 59-74.

Hiebert, J., \& Wearne, D., (2003). Developing understanding through problem solving. In H.L. Schoen \& R. Charles (Eds.), Teaching mathematics through problem solving: Grades 6-12: 3-14. Reston, VA: National Council of Teachers of Mathematics.

İraz, R. (2005). Yaratıcılık ve yenilik bağlamında girişimcilik ve KOBİler. Ankara: Çizgi Kitabevi.

Jay, E. S., \& Perkins, D. N. (1997). Problem finding, The search for mechanism. In M. A. Runco (Ed), The creativity research handbook: 257- 293, Cresskil, NJ: Hampton.

Kar, T., \& Işık, C. (2015). İlköğretim matematik öğretmenlerinin öğrencilerin kurdukları problemlere yönelik görüşlerinin incelenmesi: kesirlerle toplama işlemi. Hacettepe Üniversitesi Ĕ̆itim Fakültesi Dergisi, 30(1), 122-136.

Kayan, F. \& Çakıroğlu, E. (2008). İlköğretim matematik öğretmen adaylarının matematiksel problem çözmeye yönelik inançları. Hacettepe Üniversitesi Eğitim Fakültesi Dergisi, 35, 218-226.

Kesgin, E. (2006). Okul öncesi eğitim öğretmenlerinin öz-yeterlilik düzeyleri ile problem çözme yaklaşımlarını kullanma düzeyleri arasındaki ilişkinin incelenmesi. (Yayımlanmamış Yüksek Lisans Tezi). Pamukkale Üniversitesi, Sosyal Bilimler Enstitüsü, Denizli.

Kırnap-Dönmez, S. M. (2014). İlköğretim matematik öğretmen adaylarının problem kurma becerilerinin incelenmesi. (Yayınlanmamış Yüksek Lisans Tezi), Erciyes Üniversitesi Eğitim Bilimleri Enstitüsü, Kayseri. 
Kilpatrick, J. (1987). Where do good problems come from? In A. H. Schoenfeld, (Ed), Cognitive science and mathematics education, (pp. 123-148). USA: Lawrence Erlbaum Associates, Inc., Publishers.

Kojima, K., Miwa, K., \& Matsui, T. (2009). Study on support of learning from examples in problem posing as a production task. In Proceedings of the 17th International Conference on Computers in Education [CDROM]. Hong Kong: Asia-Pacific Society for Computers in Education.

Korkmaz, E. \& Gür, H. (2006). Öğretmen adaylarının problem kurma becerilerinin belirlenmesi. Balıkesir Üniversitesi Fen Bilimleri Enstitüsü Dergisi, 8(1), 64-74.

Leikin, R. (2009). Exploring mathematical creativity using multiple solution tasks. In Creativity in mathematics and the education of gifted students (pp. 129-145). Brill Sense.

Locke, E. A., Frederick, E., Lee, C., \& Bobko, P. (1984). Effect of self-efficacy, goals, and task strategies on task performance. Journal of Applied Psychology, 69(2), 241-251.

Nardone, C. F., \& Lee, R. G. (2011) Critical inquiry across the disciplines: Stategies for student generated problem posing. College Teaching, 59(1), 13-22.

National Council of Teachers of Mathematics [NCTM]. (2000). Principles and standards for school mathematics. Reston.

Nicolaou, A. A. \& Philippou, G. N. (2007). Efficacy beliefs, problem posing, and mathematics achievement. Paper presented at Proceedings of the V Congress of the European society for research in mathematics education (pp. 308-317). Department of Education, University of Cyprus, Larnaca (Chipre).

Özgen, K., Aydın, M., Geçici, M. E., \& Bayram, B. (2017). Sekizinci sınıf öğrencilerinin problem kurma becerilerinin bazı değişkenler açısından incelenmesi. Turkish Journal of Computer and Mathematics Education, 8(2), 323-351.

Özgen, K., \& Bayram, B. (2019). Problem kurma öz yeterlik ölçeğinin geliştirilmesi. Elementary Education Online, 18(2), 663-680

Pajares, F. (1997). Current directions in self-efficacy research. Advances in motivation and achievement, 10(149), 1-49.

Schunk, D. H., \& Rice, J. M. (1987). Enhancing comprehension skill and self-efficacy with strategy value information. Journal of Reading Behavior, 19(3), 285-302.

Silver, E. A. (1994). On mathematical problem posing. For the learning of mathematics, 14(1), 19-28.

Siswono, T. Y. E. (2011). Levels of students' creative thinking in classroom mathematics. Educational Research and Review, 6(7), 548-553.

Sriraman, B. (2005). Are giftedness and creativity synonyms in mathematics? The Journal of Secondary Gifted Education, 17(1), 20-36.

Sriraman, B. (2009). The characteristics of mathematical creativity. ZDM, 41(1-2), 13.

Stoyanova, E. (2003). Extending students' understanding of mathematics via problem posing. The Australian Mathematics Teacher, 59(2), 32-40. 
Stoyanova, E., \& Ellerton, N. F. (1996). A framework for research into students' problem posing. In P. Clarkson (Ed.), Technology in mathematics education (pp. 518-525). Melbourne: Mathematics Education Research Group of Australasia.

Şengül, S., \& Katranci, Y. (2012). Problem solving and problem posing skills of prospective mathematics teachers about the sets subject. Procedia-Social and Behavioral Sciences, 69(, 1650-1655.

Taşkın, D. (2016). Üstün yetenekli tanısı konulmuş ve konulmamış öğrencilerin matematikte yaratıcılıklarının incelenmesi: Bir özel durum çalışması. (Yayımlanmamış Doktora Tezi). Karadeniz Teknik Üniversitesi, Eğitim Bilimleri Enstitüsü, Trabzon.

Taşpınar, M. (2017). Sosyal bilimlerde SSPS uygulamalı nicel veri analizi. Ankara: Pegem Yayıncilik.

Taylor, D. W. (1960). Thinking and creativity. Annals of the New York Academy of Sciences, 91(1), 108-127.

Tertemiz, N. I., \& Sulak, S. E. (2013). Examination of problem posing skills of fifth grade students in primary education. Elementary Education Online, 12(3), 713-729.

Tierney, P., \& Farmer, S. M. (2002). Creative self-efficacy: Its potential antecedents and relationship to creative performance. Academy of Management Journal, 45(6), 1137-1148.

Torrance, E. P. (1966). Torrance tests of creative thinking: Normstechnical manual. Princeton, NJ: Personnel Press.

Turhan, B., \& Güven, M. (2014). Problem kurma yaklaşımıyla gerçekleştirilen matematik öğretiminin problem çözme başarısı, problem kurma becerisi ve matematiğe yönelik görüşlere etkisi. Çukurova Üniversitesi Ĕ̆itim Fakültesi Dergisi, 43(2), 217-234.

Yenilmez, K., \& Yolcu, B. (2007). Öğretmen davranışlarının yaratıcı düşünme becerilerinin gelişimine katkısı. Sosyal Bilimler Dergisi, 18, 95-105.

Zeytun, S. (2010). Okul öncesi öğretmenliği öğrencilerinin yaratıcllk ve problem çözme düzeyleri arasındaki ilişkinin incelenmesi. (Yayınlanmamış Yüksek Lisans Tezi). Dokuz Eylül Üniversitesi, İzmir. 